\title{
Chapter 4 \\ Catchment Areas and Killing Fields: \\ Towards an Intellectual Geography \\ of the Thirty Years' War
}

\author{
Howard Hotson
}

\section{Part I. Introduction}

\section{Intellectual Geography}

Intellectual history is traditionally text-based. Sometimes regarded as synonymous with the history of ideas, its natural starting points are the texts in which ideas are expressed and the authors who write them. Many intellectual historians now also situate authors, texts, language, and ideas in economic, social, political, and cultural contexts; and the scope of the field is now broadening further to consider the role of material objects and practices in shaping intellectual activities (Grafton, 2006; Kelley, 2002; Whatmore \& Young, 2016).

Data now offers a further opportunity to enrich the field. Digital technology affords intellectual historians the capacity to extract insight from previously unmanageable quantities of highly granular data. In a manner in some ways analogous to the focus on material culture, this capacity facilitates the writing of intellectual history from the ground up. Instead of beginning from canonical texts and working downward to explore their reception, historians can potentially situate individual texts and authors within shifting landscapes of intellectual activity, animated by huge bodies of digital data previously immobilized on the printed page.

This paper explores how one source of such data-university matriculation registers - can be used to map out one kind of intellectual exchange-student migration - at a scale and pace which makes visible for the first time patterns which structured the intellectual lives of hundreds of thousands of people across vast swathes Europe. More specifically, this paper examines the densest concentration of universities in early modern Europe at the most tumultuous moment in their

\footnotetext{
H. Hotson ( $\square)$

Faculty of History, St. Anne's College, University of Oxford, Oxford, UK

e-mail: howard.hotson@st-annes.ox.ac.uk 
history: namely, the universities of the Holy Roman Empire in the midst of the Thirty Years' War (1618-1648). After situating the topic on a broad geographical and chronological canvas (in Part I), this paper shows how even a relatively superficial engagement with this data can reveal how the war transformed the academic geography both of the Empire itself (in Part II) and of the huge catchment area which surrounded it (in Part III). After summarizing some basic historiographical and methodological results, the paper concludes (in Part IV) by outlining a few of the prospects for a more intensive engagement with this data.

\section{The Geography of Universities in the Early Modern Period: An Overview}

The medieval and early modern history of the university in central Europe is a story of sustained growth punctuated by one enormous rupture and ended by a second (Fig. 4.1). The first major crisis to hit the German universities- the Lutheran Reformation - was profound but transient. By calling into question the utility of degrees in theology and canon law, it cut matriculations in German universities by nearly three quarters in the 1530s (Asche, 2001). The longer-term effect of the Reformation, however, was to accelerate the underlying rate of growth. From the 1540s onward, enrollment in German universities grew rapidly, as inter-confessional competition and the consolidation of political authority at the territorial level increased the demand for educated officeholders, both clerical and secular. By the

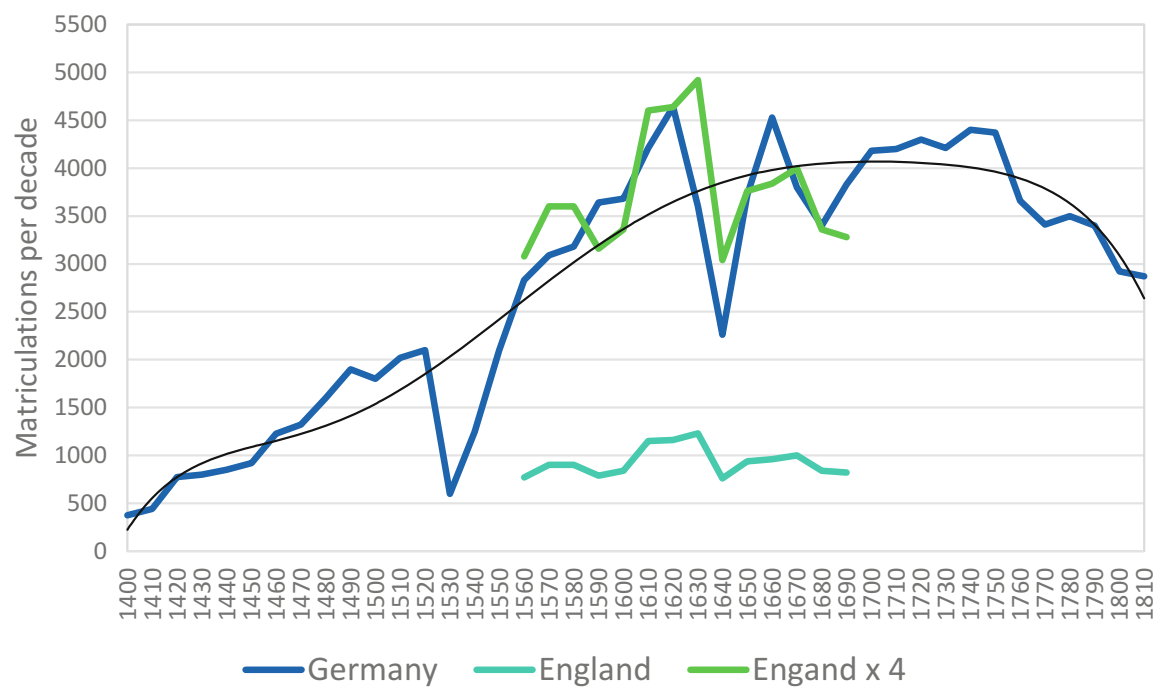

Fig. 4.1 Matriculations per decade in Germany and England.

Source: Data from Eulenburg (1904), Stone (1964). Design by author. 
1550 s, matriculations had regained pre-Reformation levels; by the 1560s, their rate of growth had recovered the pre-Reformation trend-line; from the 1590s they were growing even faster than before 1520; and by their peak in the 1620 they had grown eightfold in eight decades.

This sustained educational boom is particularly well documented for Germany thanks to the large number of complete matriculation registers surviving from this period, the publication of most of them in the nineteenth century, and the tabulation of their basic data contained within Franz Eulenburg's classic study of $1904 .{ }^{1}$ But the German case was not unique. Analogous forces produced similar effects elsewhere in Europe (de Ridder-Symoens, 1996; Frijhoff, 1986a, pp. 23-63; Julia, Revel, \& Chartier, 1986; for the English case see Stone, 1964). English university affairs, to provide one revealing comparison, were also dramatically disrupted by the reformations and counter-reformations of Henry VIII, Edward VI, and Mary Tudor. But growth resumed from the Elizabethan settlement onward, peaking in the 1630s, before the outbreak of civil war in 1642 caused enrollments to slump in perfect synchrony with the German figures.

Underlying these superficially similar trajectories, however, the geography of the English and German university systems could scarcely have been more different. Politically, the island nation unified early, and the ancient duopoly of Oxford and Cambridge suited the needs of the English crown. Instead of founding new universities, the English therefore populated the old ones with new colleges, which grew in number from 20 in 1500 to 35 in 1624. Within the Empire, by contrast, confessional differentiation and political consolidation took place at the level of individual princely territories. Each prince and imperial free city wanted their own institutions of higher education, adapted to serving their political, economic, and religious needs without exporting students to enrich their neighbors. The result was a proliferation of university and sub-university institutions without parallel elsewhere, instantly recognizable at the European scale. In 1500 (Fig. 4.2), universities were scattered across the European landscape relatively uniformly, from the middle of the Iberian and Italian peninsulas northward to southern Scotland and Scandinavia. By 1650 (Fig. 4.3), the dense concentration of universities and academies in the German principalities, the Swiss cantons, and the Dutch provinces had departed unmistakably from the European norm.

\footnotetext{
${ }^{1}$ Unless otherwise noted, matriculation data are taken from the tables provided in Franz Eulenburg (1904). Eulenburg, writing within the second German Reich, counted Königsberg amongst German universities. In the following study, Germany refers to the lands included in the current Bundesrepublik. The matriculations for Königsberg have therefore been excluded from the figures underlying this initial graph. A graph for the entire Holy Roman Empire would include Prague (1347), Vienna (1365), Louvain (1425), and a number of more recent foundations, but for many of these existing data in fragmentary. For an important refinement of Eulenburg's data on Germany, see Frijhoff (1986a).
} 


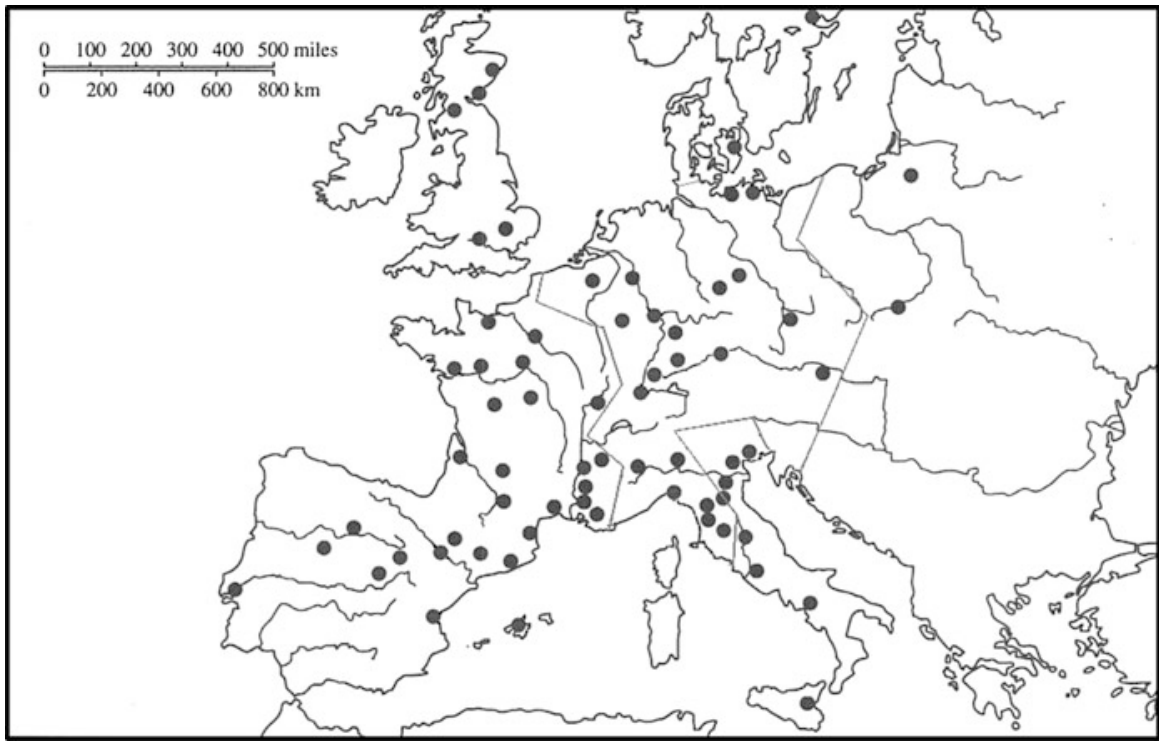

Fig. 4.2 European universities in 1500.

Source: Map derived and data taken from Frijhoff (1996, pp. 80-89). Revised map published with permission of Willem Frijhoff and the Cambridge University Press.

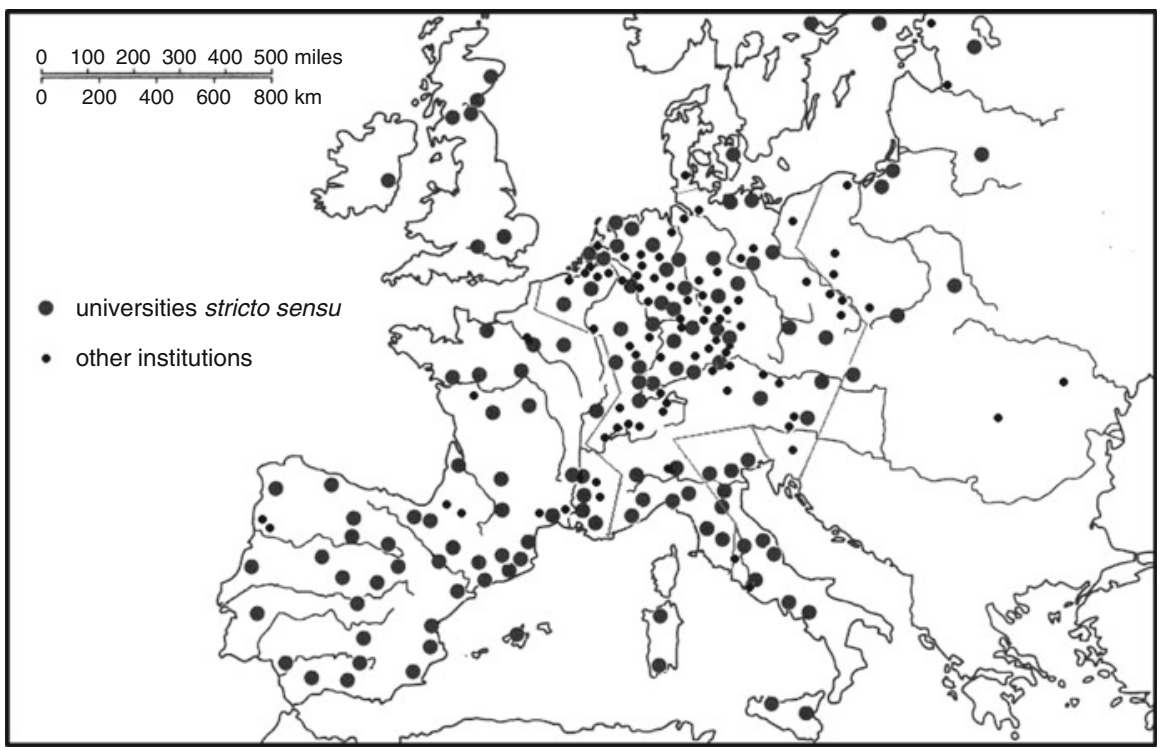

Fig. 4.3 European universities in 1650 .

Source: Map derived and data taken from Frijhoff (1996, pp. 80-89). Revised map published with permission of Willem Frijhoff and the Cambridge University Press. 
This unique academic geography had four significant consequences, which affected not only the Holy Roman Empire but a vast surrounding area as well. The first, immediately visible on the preceding maps, was institutional. In order to provide quasi-university education on the slender resources of a small principality or imperial free city, German educationalists were forced to recast the university itself in a constantly proliferating range of sub- and semi-university institutions. Most notable amongst these was the gymnasium illustre, which capped a schola classica or Paedagogium (providing pre-university education in the trivium) with a schola publica (providing streamlined introduction to the undergraduate arts or philosophy curriculum, often supplemented by one of more of the three higher faculties of law, medicine, and theology) (Siefert, 1996).

The second consequence was pedagogical. New kinds of educational institution required new educational methods, designed to impart the greatest quantity of useful learning in the shortest possible time. This requirement energized a long line of pedagogical reformers whose educational influences primarily derived from or were concentrated within the Rhineland corridor between Basle and the Low Countries: from the leading pre-Reformation northern humanist, Rudolph Agricola, via Melanchthon, Sturm, Ramus, Keckermann, and Alsted to the leading educational theorist of the wartime generation, Jan Amos Comenius (Hotson, 2007).

The third and fourth consequences played out on the broader canvas of Protestant Europe as a whole. On the one hand, these institutional and pedagogical innovations transformed Germany into the pedagogical laboratory of Protestant Europe. For over a century, these innovations radiated out from Germany in all directions alongside the better-studied theological impulses of the Reformation era. The gymnasium illustre was adapted to the needs of Prussian cities, Dutch provinces, and Scandinavian kingdoms, while the history of pedagogical practice throughout the Protestant world is, in large measure, the history of struggles to adopt, adapt, or resist the educational innovations originating from this west German tradition (Hotson, forthcoming).

While influences radiated outward, students gravitated inward, drawn by the opportunity to choose places to study at the heart of these pedagogical experiments. At its pre-war height, the German universities and academies were the center of a gigantic catchment area: their students arrived not only from German lands but from a huge arc sweeping from Hungary-Transylvania, the lands of the Czech crown, Poland-Lithuania, and the eastern Baltic to Finland, Sweden, Denmark, and Norway, and extending as far as Scotland and the Netherlands, the Swiss confederation, and even Huguenot France. ${ }^{2}$

\footnotetext{
${ }^{2}$ For Sweden: Niléhn (1983b). For Denmark-Norway: Helk (1987). For Poland: Żołądź-Strzelczyk (1996). For the Czech lands: Pešek and Šaman (1986). For Hungary: Szögi (2011).
} 


\section{The Thirty Years' War as a Turning Point in European University History}

The second great crisis to affect the German universities, the Thirty Years' War, struck central Europe at the very apex of a great academic boom 250 years in the making. So far as we know, it also struck at the very height of its international influence as a center of academic pilgrimage and a source of innovations emulated and resisted across the Protestant world from Transylvania to New England. The academic impact of the war therefore played itself out on at two different scales. The domestic level raises a series of questions regarding the effects of the war on academic affairs within the Empire. How did the chronology of academic destruction and recovery unfold over the course of three decades? Can its effects on individual institutions be grouped together to understand its broader impact on whole regions and confessions? And how did the war affect the development of the German universities after the war? The second dimension is international. How did the disruption at the center of this huge catchment area affect the long-term development of neighboring university systems across northern and central Europe, the shifting patterns of international academic migration between them, and the intellectual influences communicated by them?

For first impressions of the magnitude of these changes, we can return to the data series surveyed already. On the domestic front, Eulenburg's graph emphatically demonstrates the status of the Thirty Years' War as a dividing line between two epochs of German university history. The left-hand side of Figure 4.1 plots two centuries of gradually accelerating growth, dented but not ultimately deflected by the Reformation. The right-hand side depicts a period of stagnation followed by decline extending throughout the eighteenth century. For a century after the war, German matriculations struggled to regain their pre-war heights, declining first as a share of the population and then in absolute terms in the latter eighteenth century. Comparison with the even more anemic English recovery suggests that this pattern was neither confined to Germany nor resulted merely from the conflict in central Europe: neither the end of the British civil wars in 1651 nor the restoration of the Stuarts in 1660 restored the English university population to its prewar level. By 1700, annual enrollments had fallen to their level in 1600, ushering in the stagnation which was to characterize Oxford and Cambridge throughout the eighteenth century and beyond. The chronology of Oxbridge college foundations tells the same tale. During the 125 years before 1624, fifteen colleges were founded in Oxford and Cambridge. In the 175 years after that data, only two.

Even more striking evidence of a sea-change in German and European university history results from tabulating the data on university foundations underlying the previous maps. As Figure 4.4 shows, the rate at which new universities were founded across Europe steadily accelerated throughout the fifteenth and sixteenth centuries. The foundation of sub-university institutions (mostly Jesuit academies and Protestant gymnasia illustria) likewise climbed rapidly throughout the sixteenth and early seventeenth centuries. But the foundation of universities peaked in the half- 


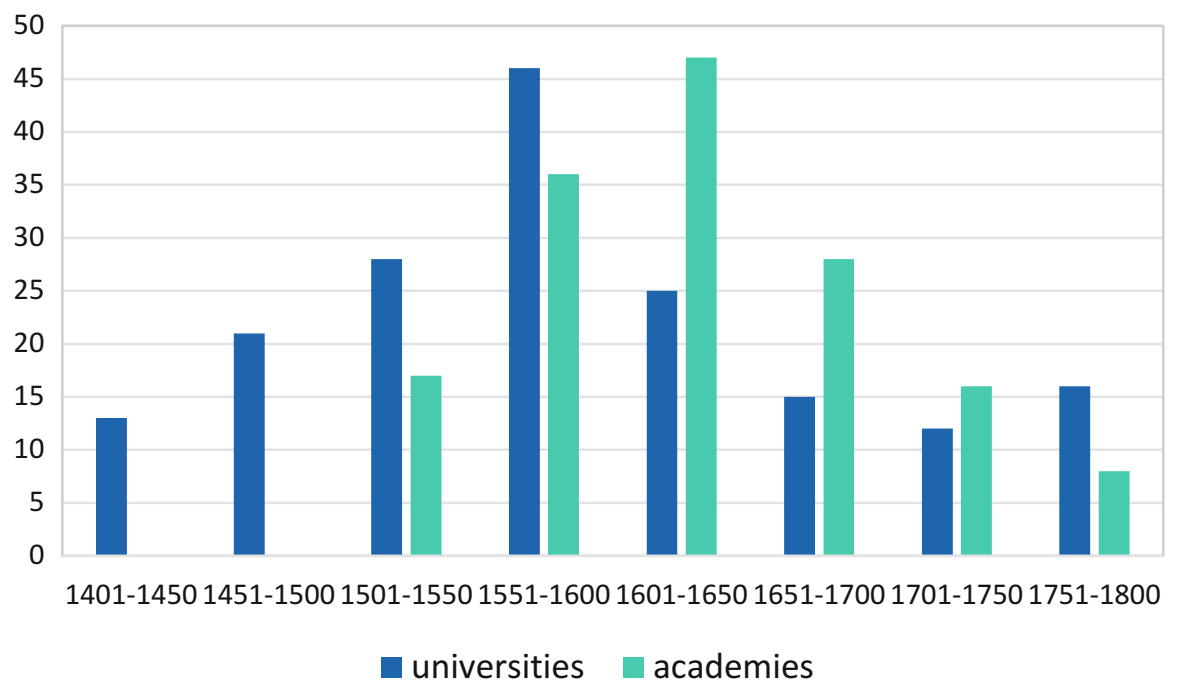

Fig. 4.4 Foundation of universities and academies in Europe, 1401-1800. Source: Data from Frijhoff (1996, pp. 80-98). Design by author.

century before 1600 , and the foundations of sub-university institutions peaked in the half-century thereafter. Both rates of foundation then fell even more sharply than they had risen, before stagnating during the eighteenth century at one third of peak levels. Whether viewed through the lens of enrollments or foundations, the confessional era, not the 'siècle des Lumières', was the great age of higher education in early modern Europe. In helping to establish this pattern, the two great central European ruptures-the Reformation and the Thirty Years' War-were crucial parts of the broader European picture: the pre-war surge in foundations of both kinds was concentrated disproportionately in the fragmented heartland of Europe; and the wartime and post-war collapse in foundations in the Empire contributed substantially to the broader European pattern.

\section{Methodological Presuppositions}

The Thirty Years' War and the other conflicts of the mid-seventeenth century-from the Northern Wars in the Baltic to the civil wars in the British Isles-therefore help mark a major turning point in the history of the university both within and beyond the theatre in which those wars were fought. Given the magnitude of this watershed, surprisingly little effort has been expended on mapping it systematically. The overwhelming majority of work on the history of German universities in this period 
remains focused on individual institutions. ${ }^{3}$ The sheer number of universities makes extrapolation from this literature difficult, and when the notorious complexity of the war itself is added to the equation it becomes obvious that grasping the scale, tempo, and texture of these changes will require a departure from the standard forms of university history. Given the diversity of experience of different confessions and regions, it is difficult to see how further case studies can form the basis of a general assessment.

Rather than diving into the archives in search of further nuance, therefore, what is most needed is to place existing historical accounts within a clear comparative framework. Such a framework can best be provided by reference to a reasonably homogeneous data set which monitors some aspect of the health of individual universities on a regular basis along a chronological axis extending before, during, and after the conflict. Since all universities need to replenish themselves on an ongoing basis, one of the most obvious indicators of institutional health is the ability to attract new students. Since universities' financial health and legal integrity also depended on keeping track of their members, matriculation records were kept meticulously throughout the German-speaking world in this period. ${ }^{4}$

This paper therefore explores the utility of matriculation data as an index of the impact of the war on individual universities and on broader academic landscapes. Its thesis is methodological as much as historical: it aims to show that matriculation data allow the impact of the war to be quantified in meaningful fashion, dated with some chronological precision, and therefore analyzed comparatively between institutions in a manner which can produce sound generalizations regarding the differentiated impact of the war on whole confessions and regions. At the level of individual universities, traditional narrative accounts will be aligned with graphs of matriculation data to determine whether matriculation registers, despite their imperfections, can provide sensitive barometers, widely distributed across the landscape of the Empire, of the pressure exerted by military events on individual institutions in specific times and places (Part II 1-3). The data for individual universities will then be aggregated in search of meaningful patterns distinguishing the experiences both of the three main religious confessions and of individual regions from one another (Part II 4-5). The scope of the study then expands beyond the boundaries of the Holy Roman Empire, in search of preliminary evidence that the iron age of university history within the war zone coincided with a golden age of some of the institutions immediately outside it (Part III). The ultimate objective is to sketch a rudimentary analytical framework within which the impact of the war can be assessed on the academic life, not only of the Empire as a whole, but of its gigantic catchment area in central and northern Europe.

The core data set for testing this methodology is provided by Eulenburg's tabulations of the German universities. Trier and Rinteln are lacking from his tables

\footnotetext{
${ }^{3}$ Valuable overviews are provided in Asche and Gerber (2008) and Rasche (2011). For the Thirty Years' War itself, see especially Kossert (2011), especially the contribution by Asche (2011).

${ }^{4}$ For a critical introduction to this genre of sources, see Asche and Häcker (2011).
} 
because their matriculation registers have not survived. The patchy data for Marburg, Giessen, and Paderborn make their experience difficult to interpret. Surviving data for Vienna, Graz, and Salzburg help put modern Austria on the map. For the southern Low Countries and the Czech lands, the data is incomplete: the matriculation registers of Prague and Douai have not survived, Leuven's is missing before 1616, and Olomouc's is fragmentary. Stepping just outside the boundaries of the Empire, Basle (the sole university in the Swiss Confederation in this period) is tightly integrated into the German Reformed academic community and reflects its experience; but Geneva is further away, less tightly integrated, and is therefore marginal to this study. Cracow and Köngisberg provide a vivid impression of the war's impact on Catholic and Lutheran communities to the east; Copenhagen, Uppsala, Tartu, and Åbo reveal its muted influence in Scandinavia; and the data from Leiden, Franeker, and Groningen clearly tie the dark age of the German Reformed universities to the golden age of the Dutch ones. More painstaking methods will be needed before the impact of the war on Italian, French, English, or Scottish academic relations can be assessed, and the same holds for the younger Dutch ones and some of the smaller institutions to the east of the Empire.

This exploratory study has been conducted, not as an end in itself, but to provide a basis for further work. The paper therefore concludes with some methodological reflections on how this approach might be expanded in a more sustained piece of collaborative research (Part IV). Obviously, such a project vastly surpasses the capacities of this brief article. What can be offered here is proof of concept of one source and method for mapping the impact of the Thirty Years' War on the intellectual geography of the Holy Roman Empire and neighboring regions.

\section{Part II. Universities within the Holy Roman Empire}

\section{Reformed Universities}

The first German university to be affected by the war, Heidelberg, was also disrupted most drastically. In the opening decades of the seventeenth century, Heidelberg was the most international university in the Reformed world, with an intake of students rising steadily to about 200 per year, two-fifths of whom came from outside Germany. Yet, by accepting the crown of St Wenseslas from the rebellious Bohemian estates in 1619, the Elector Palatine Friedrich V provoked a massive Catholic reprisal which ruined Heidelberg for a generation. The following year, as Spanish forces occupied the far bank of the Rhine, Heidelberg's rate of matriculation was cut in half. It halved again in 1621 after the Friedrich's forces were defeated at the Battle of the White Mountain, and again in 1622, by September of which year the city, the university, and the fabled electoral library were in Catholic hands. A final handful of Reformed students matriculated during the brief half-life which followed, but by 1625 the mounting program of recatholicisation had forced all the professors either to convert or to flee. Two abortive attempts to revive the ancient university followed. 


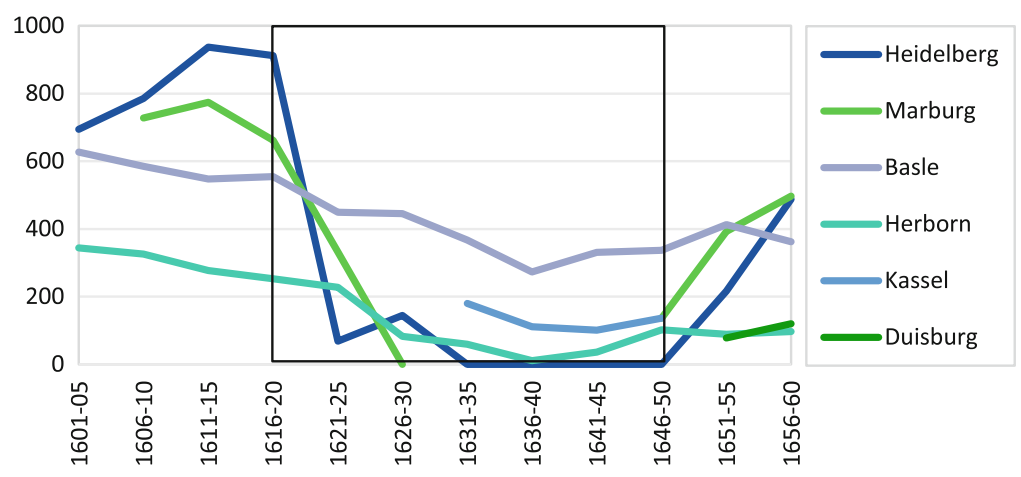

Fig. 4.5 German Reformed universities.

Source: Data from Eulenburg (1904), Falckenhainer (1893), Wachernagel (1951-1980). Design by author.

On 16 June 1629, the year after Maximilian I of Bavaria was granted hereditary status as the new Elector Palatine, Heidelberg reopened as a Catholic institution which over the next three years enrolled 145 students. But the arrival of the Swedes cut this experiment short. In October 1631, the new Jesuit professors fled the city; in December the last Catholic student matriculated; and by the end of May 1632 the city was under Swedish control. Now it was the restored Reformed regime which struggled to reassemble professors and raise revenue; but before a single student enrolled or a single lecture was held the Swedish were defeated at Nördlingen and two months later Heidelberg was re-occupied by Bavaria. In these changed circumstances, there was no thought of restoring the university: France entered the war, challenged the Bavarian electoral title and turned the Palatine lands into a battlefield once again. It was not until the Peace of Westphalia restored a fragment of Friedrich V's lands to his son that the new elector, Karl Ludwig, could refound the once great university in 1652 virtually de novo (Hautz, 1862-1864, Vol. 2, pp. 161-162; Press, 1985, pp. 314-370) (Fig. 4.5).

Less well known is the fact that the other Reformed university in western Germany-Marburg - was radically undermined for almost exactly the same period. ${ }^{5}$ Ever since its Calvinization in 1605 , the Hessian university had been a key source of strife between the temporarily ascendant Reformed Landgraf Moritz of Hesse-Kassel and his Lutheran kinsmen in the junior branches of Hesse. In March of 1624, the Lutheran Landgraf of Hesse-Darmstadt seized his chance. With the approbation of the emperor and the protection of Tilly, he invaded Hesse-Marburg, regained its university, and began legal proceedings to gain control of all the university's assets in Hesse-Kassel as well. Even the abdication of Landgraf Moritz

\footnotetext{
${ }^{5}$ For the fate of Marburg, see Hermelink \& Kaehler, 1927, pp. 220-223; von Rommel, 1820-1843, Vol. 8, pp. 528-681; on the background, see Rudersdorf, 1982; Wilson, 2009, pp. 327-328, 341.
} 
could not repair the situation, and when his son attempted to found a rival Reformed university in Kassel with less than half the means and highly unfavorable circumstances, the results were meagre. No more than six professors taught at the institution: three for theology and one each for the other three faculties. Despite letters of invitation to the chief Reformed academies in Germany, Switzerland, the Netherlands, and England, only 625 matriculations were recorded in its twenty-year history: 501 of these from within Hesse-Kassel, 94 from other German lands, and only eight from abroad (Auerbach, 1984; Falckenhainer, 1893). Not until Lutheran and Reformed universities were reunited in Marburg and Kassel was disbanded in 1652 did numbers recover to two-thirds of their average ante bellum.

The matriculation register of the third Reformed institution between Heidelberg and Marburg - the once thriving academy at Herborn — records not radically fluctuating fortunes but a gradual decline in numbers (beginning even before 1618) together with a catalogue of the woes which caused it (Zedler \& Sommer, 1908, pp. $85,86,88,92,93$, cf. 285). In 1625, it records, pauci propter calamitatem belli tristissimi huc advenerunt. In 1626, a fire, started behind the town hall by careless imperial soldiers, destroyed the greater part of the town (von Domarus, 1902-1903; Menk, 1981, pp. 62-89). In 1627, plague broke out among the ashes. In 1628-1629 the secularized ecclesiastical lands which financed the institution were lost to pre-emptive restitutions by the neighboring archbishoprics of Cologne and Trier. By 1630 all but three of the academy's professors had left for greener pastures (Menk, 1980). During the seven lean years from 1636 to 1642, only twenty students matriculated in Herborn. Although the academy recovered somewhat toward the end of the war, admissions levelled off at less than one third of their pre-war rate.

Just outside the effective boundaries of the Empire but firmly integrated into the German Reformed tradition, the university in Basle experienced a steady slide closely parallel to Herborn's (Wachernagel, 1951-1980). Basle's sharpest drop in matriculations came in 1633-1634, as the Swedish arrival in the south-west corner of the empire crowded 5,246 local refugees and their 1,776 cattle into the city of 11,000 inhabitants (Stritmatter, 1977, pp. 33-48, 64-68). But as the gradual downward drift of matriculations indicates, the university's problems went deeper than the ephemeral shocks of war. Basle had opened the seventeenth century as a strikingly international Promotionsuniversität, where not only Reformed theologians but central European students more generally took doctorates in law and medicine upon returning to the threshold of the Empire after studies in Padua, Bologna, Siena, or Montpellier (Bonjour, 1960). The demise of Heidelberg, Marburg, and Herborn cut the network of Reformed institutions which channelled theology students to Basle from the north; the rise of Leiden was to divert students of law and medicine from Italy to Holland; and Basle declined gradually to finish the 
century as one of the smallest and least significant universities in central Europe (Staehelin, 1957, pp. 52-57, 86-98). ${ }^{6}$

\section{Catholic Universities}

If the Reformed institutions were hit first and hardest, their Catholic counterparts were at first virtually unaffected. Against the background of uninterrupted imperial military success, the overall level of annual matriculations in Catholic universities remained almost perfectly steady in the years before 1630 . With the arrival of the Swedes in subsequent years, however, each of the five Catholic institutions in southern Germany-Würzburg, Mainz, Ingolstadt, Dillingen, and Freiburg—saw their recruitment fall by eighty to one hundred new students per year. As in the case of the Reformed universities, it was the smaller Catholic institutions in the RhineMain region which suffered first and most. In the four years after the Swedes captured Würzburg and established the administration of their occupied territories in Mainz in 1631, these two universities ceased to function completely (Roberts, 1953-1958, Vol. 2, pp. 548, 558, 621) (Fig. 4.6).

The bishopric of Würzburg-long a pillar of counter-reformation in the center of Germany and a founding member of the Catholic League-surrendered after minimal resistance to the Swedish king on 15 October 1631, barely two weeks after his first great victory at Breitenfeld. 'With the enemy already approaching the city,' the Jesuit polymath Athanasius Kircher later recounted, 'the whole Jesuit college broke up within twenty-four hours' in complete confusion. Impelled by the terrible rumor that the Swedes would leave no Jesuit caught in the city alive, Kircher was swept with the tide of his brethren to Mainz, Speyer, and eventually to France. After shipping the city's rich libraries to Sweden, Gustavus combined Würzburg and the neighboring bishopric of Bamberg into a new duchy of Franconia and granted it to his leading general, Bernhard von Weimar. The new duke planned first to turn the

\footnotetext{
${ }^{6}$ Geneva—further removed from the Empire and less tightly integrated into the German Reformed academic world - played out a rather muted variation on Basel's theme. Before the war, its trend was manifestly downward; the first decade of the war prompted a brief recovery; but thereafter the downward trend only accelerated, and during the final decade of the war, Geneva enrolled less than 40 percent of the students enrolled during the first decade. Detailed research is needed to investigate these contradictory movements, but both the growth and the decline could be readily explained by reference to the war to the north. Between 1618 and 1628, Geneva may have benefitted from the displacement of students following the lost Heidelberg and Marburg and the demise of Herborn; but as new patterns consolidated around the Dutch universities in subsequent decades, Geneva may have found itself cut off from the academic trade routes which had previously supplied most of its non-Francophone students. Further detail will be found in Stelling-Michaud (1959-1980). I have been unable to consult the dissertation of Bernhard Troesch (1969). The bi-confessional university in Frankfurt-an-der-Oder is difficult to situate in this study. It is discussed in section II. 3 below, since its pattern of matriculations closely resembles those of its Lutheran neighbours in northern Germany.
} 


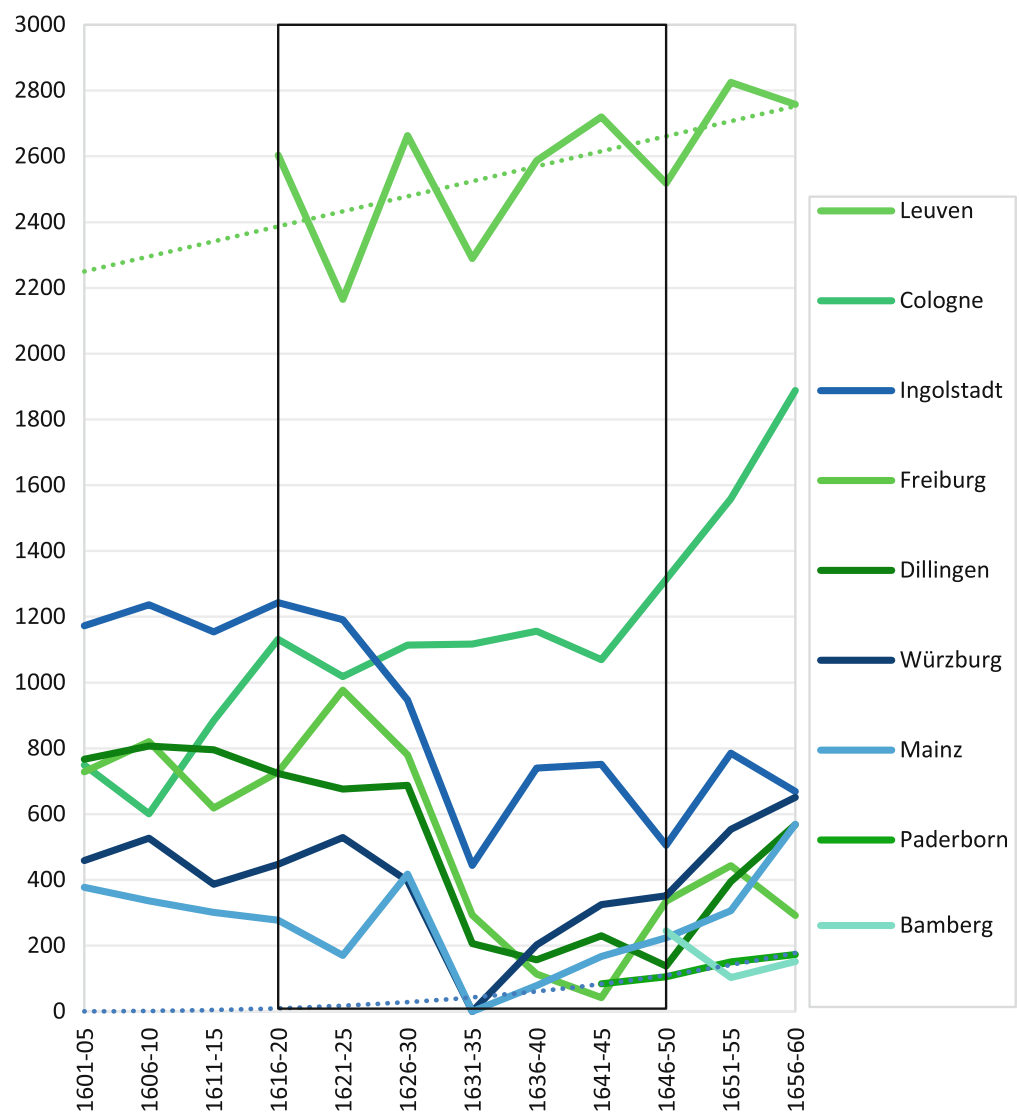

Fig. 4.6 Catholic universities in Germany and the Spanish Netherlands.

Source: Data from Eulenburg (1904), Schillings (1962-1963). Design by author.

city's university and two Jesuit colleges into an academy for educating young noblemen, to be named after the Swedish king himself. He then considered resurrecting the university and its gymnasium as a key instrument of the reintroduction of Protestantism into Franconia. But scarcely a month after the Swedish defeat at Nördlingen, Würzburg was retaken by imperial troops. The Catholic bishop, clerics, and professors returned from sanctuary elsewhere, but the reopening of the university was delayed by the need to replace some 5,000 books stolen by the Swedes from the library. Matriculations recommenced on 1 October 1636, and within a few years they had regained roughly their previous level (Schonath, 1967; von Wegele, 1882/1969, pp. 57-62, 476-479; Weber, 1979).

The story played out a few months later down-river in Mainz had a similar beginning but a less happy ending. On 18 December 1631, the elector-archbishop fled the city to join the bishop of Würzburg in exile in Cologne. Five days later, on the very day of the capitulation of the Spanish garrison, Gustavus Adolphus once again ordered the transportation of the elector's library to Sweden. In Mainz the 
Swedes dug in even deeper, intending to make this state at the crossroads of Germany the capital of their new, evangelical, imperial order. When forced to leave in January 1636, they left an even more complete ruin behind them. The city lost a quarter of its houses, two fifths of its residents, and two thirds of its property; a great part of the university archives perished, and even the feeble recovery of student numbers was stalled by the French occupation of the city in 1644-1648 (Binz, 1917-1918; Brück, 1972; Frohnhäuser, 1899; Just \& Mathy, 1965, pp. 21-23).

Gustavus' entry into Bavaria in 1632 was marked by a siege of the heavily fortified Ingolstadt, a bulwark of the duchy's defenses, with the duke (and now elector) Maximilian pinned down inside and his wounded general Tilly dying in the house of the city's law professor. Coming on top of the hyperinflation of the early 1620 s and the disastrous harvest of 1626, Ingolstadt's intake of new students dropped to just 20 percent of its pre-war peak, but the crisis was short-lived. Unable to break through some of the strongest fortifications in Germany, the Swedes were forced to withdraw. Within two years, enrollments had bounced back to about two-thirds of their previous level, only to be dented by an outbreak of 'Hungarian fever' in 1634-1635. The systematic plundering of Bavaria in the last years of the war, coinciding with another outbreak of plague, cut matriculations to their absolute low point in 1648-1649; but very few of Ingolstadt's native sons elected to leave their impregnable home town to study in other universities during these years. Its combination of Landesfestung and Universitätsstadt made Ingolstadt a place of relative safety and stability, at least by the dismal standards of the 1630s and 1640s (Prantl, 1872, Vol. 1, pp. 376-378; Roberts, 1953-1958, Vol. 2, pp. 703-704; Schönauer, 2006, 2007, 2011).

The nearby university of Dillingen was less well defended. As the Swedes advanced, its numbers fell rapidly by 70 percent and were to remain low until the very end of the war. The city surrendered without resistance on 9 April 1632 in return for guarantees that Catholicism would be maintained. The Swedish king took the Jesuit faculty under his personal protection and relations with the Swedish governor began cordially. Lectures, services in the university chapel, and even the granting of academic degree continued without interruption throughout the war, although the latter took place without the university mace, which had been buried to protect it from the enemy. But the absence of such insignia must have been suspicious, rumors circulated that great treasures were hidden in the Jesuit college, and the Swedish governor exerted great pressure on college officials in attempting to find them. ${ }^{7}$ The worst came-ironically but not uncharacteristically for this conflict—with the recapture of the city by imperial troops: even the university acts

\footnotetext{
${ }^{7}$ According to one rumour, 40 wagonloads of treasure had been removed to the Tyrol for safekeeping. According to the famous Paracelsian prophecy of the 'Lion of the North' (commonly applied to Gustavus Adolphus), at the culmination of his campaigns a stone of immeasurable value would be found somewhere between Swabia and Bavaria. The Swedish governor in Dillingen, David von Osten, believed that this treasure would be found amongst the city's Jesuits. After searching every corner of the Jesuit college without success he thrice imprisoned various clerics and officials, from the rector and episcopal chancellor on down, in attempting to press huge financial contributions from them.
} 
complained that the Swedes inflicted nothing on the city to compare with its dreadful plundering by the Croats (Specht, 1902/1987).

When the turn of Freiburg im Breisgau arrived in 1633, it heralded a decade of pitiful enrolments. The reason was the nearby fortress of Breisach, which straddled the 'Spanish road' from Milan to Brussels, controlled access across the Rhine from France, and was therefore contested by all the main parties in the south-western theatre of the war. In 1632, the Swedes besieged both the fortress and the nearby city of Constance. In 1633, the duke of Feria, governor of Spanish Lombardy, marched 20,000 men through the Valtelline to relieve them. Freiburg — caught between the two sieges, and occupied first by the Swedes, then by imperial forces, and eventually recaptured by Sweden — saw its intake of students fall to a single pair (Beyerle, 1900; Häcker, 2011; Pagès, 1970; Parker, 1984, p. 132). Like its Lutheran neighbors in the south-western corner of the Empire, Freiburg suffered further losses with the French entry into the war: in the seven years between the French siege of Breisach in 1638 and the battle of Freiburg in 1644 (one of the war's longest and toughest), Freiburg was occupied twice more, and the university enrolled only 62 new students (Parker, 1984, pp. 152, 153, 163, 175-176; Wilson, 2009, pp. 678-684). By this time war had returned to Bavaria and dented the recovery of Ingolstadt as well. The great battle at Nördlingen in 1645, the final Swedish plundering of Bavaria in 1646-1647, and Mazarin's crushing defeat in the battle of Zusmarshausen as late as 17 May 1648 temporarily cut Ingolstadt's recruitment by 60 percent. The defenseless Dillingen was plundered by French and Swedish armies three times in the closing years of the war, and the latter did not leave entirely until 1650 .

These five Catholic institutions thus shared a similar fate, yet the partial exception of Ingolstadt is noteworthy. The impression that this heavily fortified university city might mark the boundary between the main corridor of destruction and the more protected lands to the south and east is confirmed by the experience of the other universities in the region: the ancient university of Vienna, the recently-founded Jesuit university in Graz, and the Benedictines' war-time foundation in Salzburg (Fig. 4.7).

The contrast of their experience with the wildly fluctuating fortunes of their German coreligionists is immediately apparent. So too is their long-term upward trend. Yet caution is needed. Detecting the immediate, negative impact of warfare on matriculation rates is relatively simple: one must merely correlate a dramatic downturn in matriculations with a military event directly effecting the university city in question, which is often noted by contemporaries within the matriculation register itself. Demonstrating the indirect, positive impact of warfare on matriculations is a more painstaking business. Ideally, it requires knowledge both of the catchment areas of whole clusters of universities before the war and of the way in which military events disrupted those areas, undermining some institutions while benefitting others. Failing that, one can deduce the impact of the war less securely by studying changes in the geographical origins of students at a single institution. When that data is lacking, shifting matriculation rates can only suggest the likelihood that further work might reveal a more demonstrable relationship between the rise of some institutions and the decline of others. 


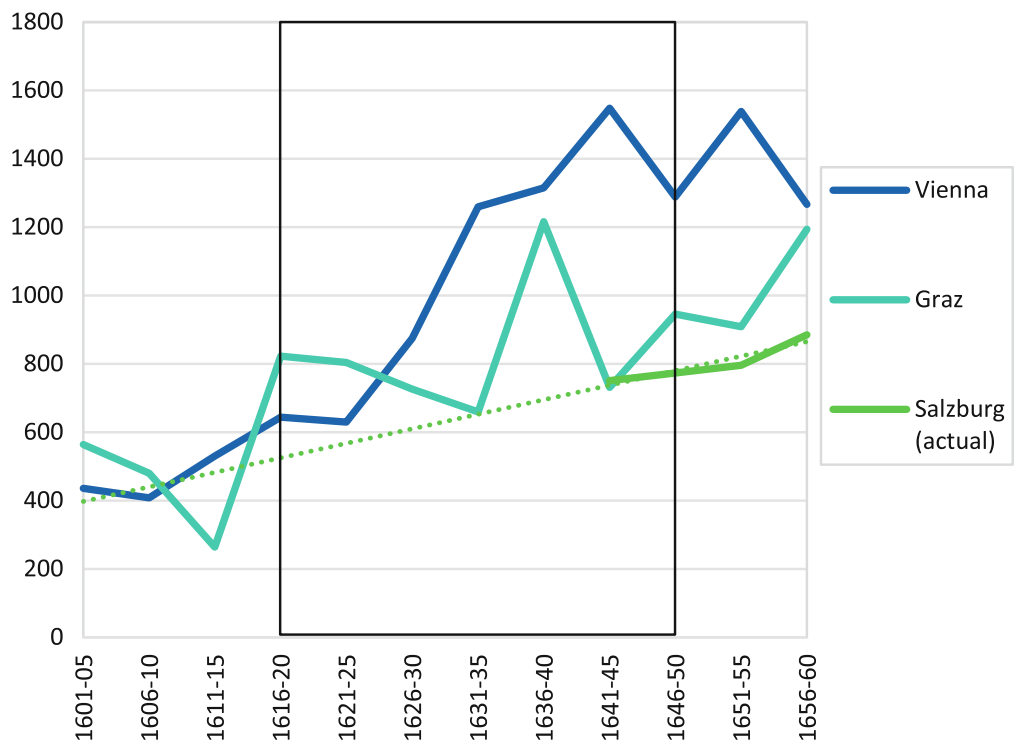

Fig. 4.7 Catholic universities in the southeast: Vienna, Graz, and Salzburg.

Source: Data from Andritsch (1977-1980), Gall and Paulhart (1974), Redlich (1933). Design by author.

Vienna's experience is a case in point. Its pattern of enrolment suggests that it benefitted from the chaos inflicted by the war to the north and west, but painstaking work will be required to confirm this hypothesis. As Swedish armies devastated Catholic universities on the Main, the Rhine, and the upper Danube in the early 1630s, Vienna's matriculations nearly doubled. After gentler growth for a further decade, Vienna was enjoying a rate of inscription two and one half times greater than before the war. Its peak of 520 matriculations in 1643 eclipsed even Leuven and Leiden to make Vienna, momentarily, the most heavily frequented university in central and north-western Europe. The synchronization of these countervailing developments-German disaster and Austrian flourishing-seems too obvious to be coincidental; yet until the Viennese register has been carefully analyzed, it will remain unclear how much of this growth results from the direct displacement of German students and how much from the reorientation of academic trade routes from the east which had previously been centered on or shared with Germany (Gall \& Paulhart, 1974).

The better-studied Graz register reveals some of the trade-offs involved. Located in the duchy of Styria south of Vienna, this Jesuit university was sheltered from antiimperial forces and also from the surge of students displaced by them. It was not until the latter 1630s that a wave of new recruits reached Graz. During this period, the number of Bavarians in Graz rose significantly; but these gains were counterbalanced by falling numbers of Swabians and Rhinelanders. Apparently, 
the military corridor which the Swedes had cut diagonally across southern Germany not only displaced students from within it: it also hindered mobility across it. Although the attractiveness of Graz to Catholics south and east of this corridor was increased, its accessibility to those to the north and west was diminished. Thanks to these contradictory forces, the German matriculations in Graz rose by only 13 percent during the war. Revealingly, they were then cut in half in the 1650s, as affairs to the north and west began to recover. Yet on balance Graz had a good war: a period of growth during the 1640s left it eighty percent larger at the end of the conflict than at the beginning (Andritsch, 1977, Vol. 1, p. xxix, 1980, Vol. 2, p. xxvi). ${ }^{8}$

To what extent this upward trend was shared by the Benedictine university founded in Salzburg in 1620, opened in 1622, and fully privileged by 1625 , is impossible to say with certainty, since its matriculation register only survives from 1639 onward (Redlich, 1933). Its fortunes thereafter are not quite as serene as Figure 4.7 appears to indicate-coincidentally or otherwise, Salzburg's matriculations were cut in half the year following the conclusion of peace in Westphalia-but they had fully recovered within five years, and the overall trend is one of gentle growth. In any case, the general trajectory of this cluster is clear: annual matriculations in universities south-east of Bavaria nearly trebled from their average in the decade before the war (227 in 1611-1620) to the decade after it (646 in 1651-1660). The question is not whether they benefitted from the conflict, but whether they did so directly (from displaced German students) or indirectly (by altered patterns of international student migration), as seems more likely.

Vienna and Graz do not, however, mark the eastern limit of this effect. The matriculation register for Prague does not survive for this period, that for Olomouc is fragmentary, and the smaller universities in Poland-Lithuania and Upper Hungary await closer study. ${ }^{9}$ But the shockwaves of the Swedish arrival in Catholic Germany were powerfully felt as far east as Cracow. In 1632, matriculations in the Jagiellonian University suddenly doubled; and they remained sky-high for another three years before suddenly falling back to their early seventeenth-century average in 1636 (Zathey \& Barycz, 1950). Polish scholars have found nothing in the domestic situation to explain this dramatic rise and fall (Kaniewska, 1986, pp. 136-137, 146). Placed within a broader context, however, their origin is obvious. This spike in matriculations is by far the most dramatic of any university east of the Rhine in the seventeenth century, and probably the most dramatic anywhere in Europe in this period. It comes in the midst of the Swedish assault on Würzburg, Mainz, Ingolstadt, Dillingen, and Freiburg between October 1631 and 1633, and before the first clear evidence of rising numbers in Vienna in 1634. Cracow's huge spike therefore clearly

\footnotetext{
${ }^{8}$ The figures for the decades beginning in $1621,1631,1641$, and 1651 are as follows: Bavaria: 47, 72, 66, 26; Swabia: 57, 40, 64, 48; Franconia: 16, 18, 16, 6; Rhineland: 20, 11, 12, 2; other German regions: 14, 15, 17. 9; total German matriculants: 154, 156, 175, 91.

${ }^{9}$ Similar effects should be sought in smaller institutions in Bratislava / Pózsony (founded 1465), Braniewo / Braunsberg (1568), Vilnius (1578/79), Zamość (1594), and Tyrnava (1635). See Lühr (1925) and Zsoldos (1990).
} 
registers the seismic shock radiating outward from the greatest disaster in the postReformation history of central European Catholic higher education. The only question is whether these additional matriculants are German students fleeing the Swedes or, as seems more likely, Catholic students from Poland-Lithuania, Hungary-Transylvania, and perhaps also the lands of the Bohemian crown who might otherwise have studied further west but who gravitated in the immediate aftermath of the crisis to the safety of Cracow instead.

What then of the Catholic universities to the north and west of the corridor of destruction running diagonally from eastern Pomerania to Breisgau? Returning to Figure 4.6 suggests that they escaped the disasters visited on their neighbors, but did not benefit from them in the manner of Vienna or Cracow.

The oldest of the German Catholic universities is the crucial case. Throughout the late sixteenth century and the first years of the seventeenth, Cologne profited little from the general educational boom, but on the eve of the war its numbers grew strongly. The city's geographical position to the north-east of the main military movements subsequently shielded it from direct military entanglements, and its strenuous assertions of neutrality, backed by generous payments to passing armies, spared it the calamities visited on most other German centers. Commercially, it prospered from arms manufacture and trade, by providing credit to Catholic combatants, and through the maintenance of good relations with the Dutch Republic. Famous as a gathering point for Catholic leaders planning the recovery of assets lost to Protestant forces, it was the natural place of refuge for students and professors fleeing Würzburg and Mainz. Meanwhile, the approaches from the west for students from its traditional catchment area in the Spanish Netherlands remained open (Bergerhausen, 2010, pp. 222-223; Methuen, 1988, pp. 329, 331-332). All told, Cologne remained the least affected of all German universities of any confession throughout the conflict; but when combined with her dramatic spurts of growth immediately before and after the war, her general trend in matriculations was emphatically upward.

How much the young university of Paderborn, northeast of Cologne, shared these fortunes is unclear. Although founded just before the war, its matriculation register only survives from 1637 onward. For the next six years, it recorded an average of only twenty new students per year. Growth was detectable from 1643, after the worst had passed for the German Catholic institutions to the south but before they began to grow as well. The attempt to found a university in Osnabrück also presented a mixed picture: no sooner had it obtained papal privileges in 1629 and imperial privileges in 1632 than it closed in 1633. In 1648, the first new Catholic university since Salzburg was established in Bamberg, in the middle of what was previously the military corridor, reinforcing the now well-established upward trend and helping to mark the end of a traumatic period.

Nearly 200 kilometers due east of Cologne, Leuven's relationship with the central European conflict is not easy to perceive from matriculation rates alone. In Leuven, disruption was more evident in the pre-war period, in which the city was repeatedly occupied by foreign troops waging the war between Spain and the rebellious Dutch provinces. Between August 1569 and February 1616, not even its matriculation 
register survives. By the time the record resumes, however, stability had been re-established; and for the next half century, the matriculation rate fluctuated relatively little around a very gentle upward trend. Proportionately, the effect was not huge: the university was less than ten percent larger at the end of the war than at its beginning. Yet, given the large size of Leuven, this still represented a net gain of some 40 matriculants per year (Lamberts \& Roegiers, 1990, p. 28; Schillings, 1962-1963, Vol. 5, pp. ix-x; Vol. 6). All told, Leuven matriculated 13,813 students between 1618 and 1648, nearly as many as the second and third-ranked Catholic universities in the Empire-Vienna $(6,832)$ and Cologne $(7,031)$ - put together, far more than Königsberg $(8,193)$ and Wittenberg $(10,640)$, more even than the fabled Leiden $(13,448)$, and second only within the Empire to the Saxon giant: Leipzig $(15,838)$.

The main university of the Spanish Habsburg's Netherlandish provinces, Leuven thus provides an illuminating contrast to Vienna, its counterpart in the Habsburg patrimonial lands. Vienna more than doubled in size during the Thirty Years' War because its sheltered position in the southeast benefitted not only from German students displaced by the war but also, and perhaps primarily, by accommodating students from Hungary, Poland, and the Czech lands who might otherwise have studied in Germany. Leuven's northeasterly location was situated very differently with respect to international academic trade routes. Its neighbors to the north (the predominantly Protestant Dutch Republic) and the south (a Catholic country, but one abundantly furnished with universities of its own) were not part of the German Catholic universities' natural catchment area; so the disruptions east of the Rhine did not channel fresh streams of students from northwestern Europe to Leuven during the wartime period.

Yet Leuven was not as immune from the effects of the war as its bare matriculation rate at first suggests, due to the rekindling of conflict between France and Spain. After Sweden lost its German Protestant allies in the Peace of Prague, a general cessation of hostilities favorable to the Habsburg looked likely. To prevent this, France followed its longstanding financial support for the Swedish war effort by declaring war on Spain in 1635 (Parrott, 1987). The French siege of Leuven that same year provoked the only sharp drop in Leuven's rate of matriculations during the ensuring conflict (van Nimwegen, 2014, pp. 170-171; Wilson, 2009, p. 560). The wartime peak in Leuven's enrolments in 1641 was also a consequence of warfare. Douai, the second and more southerly university of the Spanish Netherlands, found itself in the front line of war with France and suffered terribly: its estates were despoiled, its finances ruined, its damaged buildings repurposed as barracks for troops and a hospital for the wounded, and plague scattered even the permanent citizens, until the city and its environs were finally captured by the armies of Louis XIV in 1667 and permanently annexed to France in the Treaty of Aix-la-Chapelle the following year (Dehon, 1998, pp. 23-34). Unsurprisingly, as the annalist of its College of Anchin complained as early as 1640, students fled Douai in droves for the greater security of Leuven. The loss of Douai's matriculation register makes this transfer difficult to quantify without a meticulous reconstruction of Leuven's shifting catchment area in these years. Nevertheless, it seems likely that Leuven, although 
buffered from the effects of the war in Germany, may have benefitted, on balance, from the related conflict in Artois and Flanders.

\section{Lutheran Universities}

Even more directly than Catholic ones, Lutheran universities seemed initially to benefit from the outbreak of war. The only two universities ever founded in imperial free cities - Strasbourg and Altdorf-owed that status to adroit diplomacy in the first years of the conflict (Schindling, 1978) (Fig. 4.8). Strasbourg's strategically important location as the nearest large city to Heidelberg produced two key benefits at the outset of the war. As Catholic armies closed in on the Palatinate in 1621, skilful diplomacy won from the emperor a charter raising the city's famous academic gymnasium to full university status as a reward for Strasbourg's withdrawal from the Protestant Union (Schindling, 1977, pp. 72-77). The closing of Heidelberg the following year also provided the new university with important fresh sources of students: 50 young men from the Palatinate enrolled in Strasbourg in its first nine years - more than in any other Lutheran university, or indeed than any Reformed institution besides Leiden and Basle (Persijn, 1959, pp. 40-42 and appendix). ${ }^{10}$ Nuremberg's location in the delicate region near the Upper Palatinate, Bohemia, and Bavaria was no less crucial, and the city's withdrawal from the Union in 1622 was soon repaid when its gymnasium in Altdorf was granted university statutes two years later (Schindling, 1978, pp. 166-167).

Even these uniquely fortunate southern Lutheran universities, however, could not escape the less benign effects of three decades of war. After eight years of sustained prosperity, Altdorf's matriculations fell briefly to zero in the summer of 1632, as Gustavus' 45,000-strong army dug in on the outskirts of the Nuremberg, Wallenstein's army attempted to starve it out, and the Swedish chancellor, Axel Oxenstierna, arrived with a third army to destroy the resources sustaining Wallenstein's horde (Parker, 1984, p. 130; Roberts, 1953-1958, Vol. 2, pp. 717-720, 726-733). Altdorf's crisis therefore arrived half a decade before the general nadir of the Lutheran universities in the latter 1620s. As the young university's fortunes vacillated over the next decade, the rector of Altdorf struggled intermittently to prevent the patricians of Nuremberg from closing the institution altogether (Ernstberger, 1966). Yet although its numbers remained modest, its overall experience was relatively benign by the terrible standards of the era.

Tübingen, the third of the smaller and more southerly Lutheran universities, retained healthy enrolments two years longer until 1634, when the young Duke Eberhard III of Württemberg, having reached majority, allied his duchy with the previously unbeatable Swedes. In the Swedish defeat at Nördlingen a few months

\footnotetext{
${ }^{10}$ During the same period Strasbourg replaced Heidelberg as the favourite university of students heading to or returning from Basle (Frijhoff, 1986a, p. 42).
} 


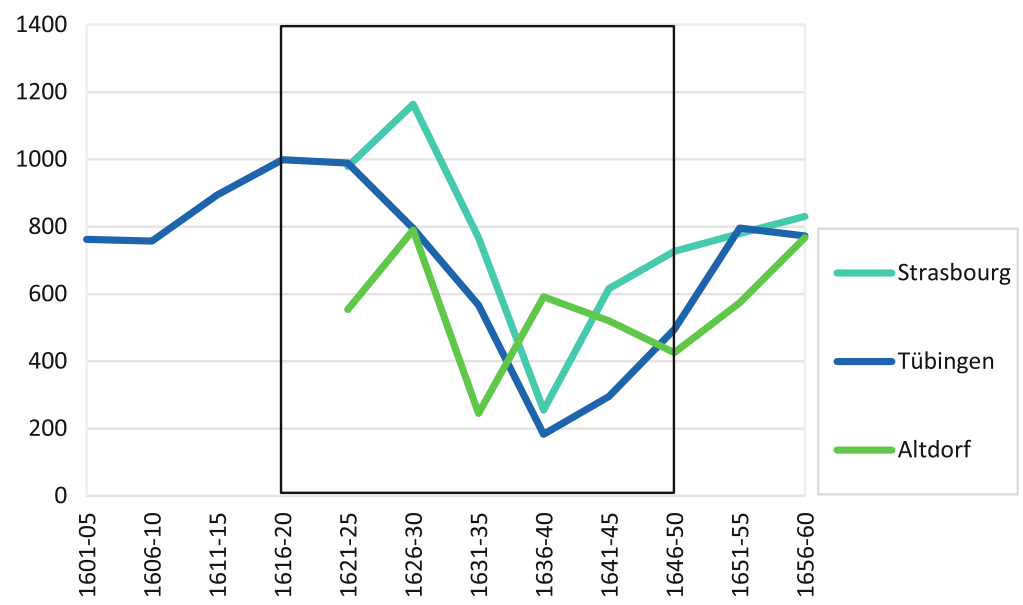

Fig. 4.8 Lutheran universities in southern Germany, 1601-1660.

Source: Data from Eulenburg (1904). Design by author.

later, the duke lost two-thirds of his army. Eberhard fled the next day with his treasury into exile in Strasbourg, and for the following four years his duchy was occupied by Habsburg forces which rigorously enforced the restitution of the rich monastic lands upon which his state and university jointly depended. In 1635, the libraries of the duke and the Collegium illustre were packed off to Munich and plague swept through the university, killing nine professors. By 1639, faculty numbers had been cut in half, matriculations had fallen by four-fifths, the professors' incomes had disappeared almost completely, and the university library had been decimated as well, as its most precious volumes were sold to meet the never-ending demand for contributions. French intervention in Württemberg in 1646 extended this dismal period further, and numbers in Tübingen rose only feebly before the French general, Turenne, personally returned the city to Duke Eberhard III on 27 November 1648 , after which they bounced back quickly, if not quite to pre-war levels (DeckersHauff \& Setzler, 1977, pp. 126-140; Klüpfel, 1849/1977, pp. 136-142; Schreiner, 1985; Vann, 1984, pp. 93-97; Zaschka, 1993, pp. 44-47, 155-157, 179-183). Strasbourg-more firmly ensconced within the French protectorate on the left bank of the Rhine-was to experience a later decline in 1635 and a more rapid and sustained recovery from 1641 onwards.

Of the northerly universities, the fashionable, young Helmstedt suffered first, most drastically, but also most briefly (Fig. 4.9). Caught in the middle of the DanishLower Saxon phase of the war, it followed a rhythm of disaster and recovery earlier than either its larger Saxon neighbors or the smaller Lutheran universities far to the south. Helmstedt's numbers faltered momentarily as early as $1622-1623$, following the sudden death of three of the university's six theology professors and the very first incursion of the war into northern Germany: the skirmishes of Tilly and Christian 


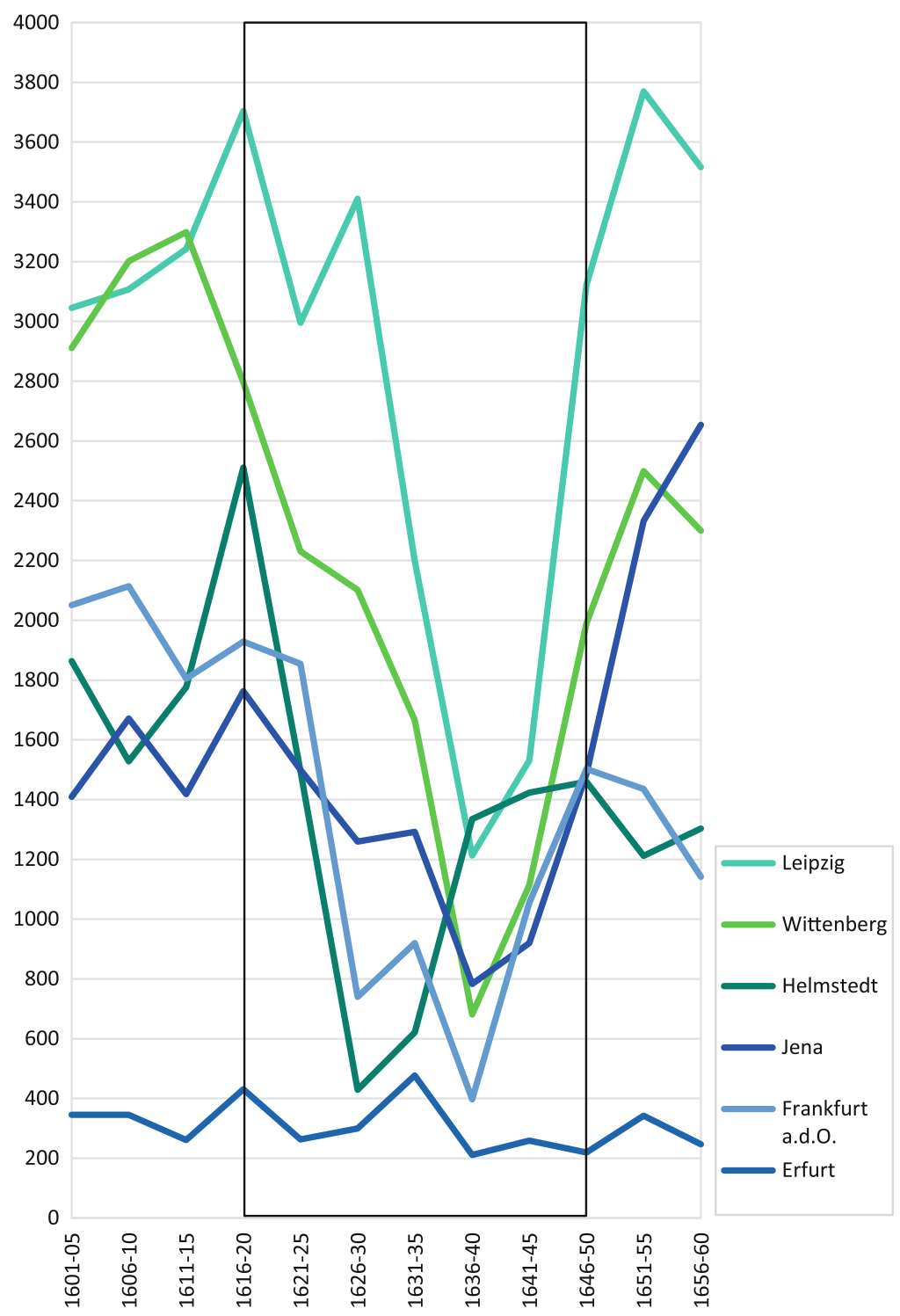

Fig. 4.9 Lutheran universities in northern Germany.

Source: Data from Eulenburg (1904). Design by author.

von Halberstadt in the Leine Valley, the Plesse, and the area around Braunschweig. Students streamed back in 1624 only to desert the university almost entirely in the following years as Christian IV of Denmark took up headquarters in nearby Wolfenbüttel, imperial forces moved northwards through the Harz, Duke Friedrich Ulrich deserted his lands for the sanctuary of the neutral free city of Braunschweig, 
plague broke out in Helmstedt, and the region passed into Habsburg control after the Danish defeat at Lutter. The arrival of Wallenstein's troops in 1628 and the extinction of the ruling branch of the house of Braunschweig-Wolfenbüttel in 1634 twice dented the university's recovery. But even in these trying times Helmstedt's academic reputation was bolstered through the appointment of such notable professors as the leading Lutheran irenicist, Georg Calixt, and the celebrated polyhistor, Hermann Conring. Following the recovery of dynastic stability under the passionate bibliophile, Duke August of Braunschweig-Lüneburg, in 1636, matriculations recovered strongly in 1637 and Helmstedt entered into a second period of prosperity. Despite repeated fighting over the occupied capital of Wolfenbüttel in 1638 and 1641 , three-quarters as many students entered the university in the final third of the war as in the peak decade before it. Thanks to the devastation visited on nearby Saxony, Helmstedt admitted more students than any other German university in 1637, 1639, 1640, and 1643 (Alschner, 1998, pp. 65-79, 100-110; Eulenburg, 1904, p. 291; Hofmeister, 1907; Triebs, 1995, pp. 16-19).

The three large Saxon universities-Leipzig, Wittenberg, and Jena-also suffered temporarily from their proximity to the fighting in the mid-1620s, during which the armies of the Danish king as Kreisoberst of Lower Saxony, his allies, and his enemies moved back and forth across their territory (Parker, 1984, pp. 57-58; Richter, 2011). But their losses were relatively slight and they recovered strongly in 1627 and 1628, almost regaining their high-point of ten years earlier. Despite an outbreak of plague the year before, in 1627 the elector Johann Georg could still boast that Leipzig occupied the first place among evangelical universities. But just as electoral Saxony suffered worst in the years which followed, Leipzig - a major commercial crossroads in time of peace-became a favorite battleground in time of war, especially after the Edict of Restitution and the arrival of the Swedes persuaded the Saxon elector to break his earlier alliance with the Emperor in the autumn of 1631. The first and last great battles of Gustavus Adolphus's German campaign-Breitenfeld on 17 September 1631 and Lützen on 17 November 1632took place within a few kilometres of Leipzig; a second main battle at Breitenfeld followed in 1642; and with each main conflict Leipzig was besieged. The juridical faculty found itself in a particularly unfortunate strategic position: its buildings-the Ordinariatshaus and the Collegium Petrinum-offered a semi-fortified position with a clear line of fire on Leipzig's citadel, the Pleißenburg. In 1632, the imperial general, Holke, shelled the Pleißenburg from the Ordinariatshaus and returning fire from the fortress wrecked havoc with neighbouring buildings. After Lützen the story was repeated with roles reversed: the Saxony artillery firing from the university premises, the imperial forces firing at them. After a fierce storm completed the devastation in 1634, the Ordinariatshaus was described in one bitter faculty memo as 'nicht mehr als ein Eulennest' ('no more than an owl's nest'). In 1641, even these ruins were swept away to make room for soldiers' quarters; and between these dates matriculations in Leipzig sunk to barely one quarter of their pre-war high (Friedberg, 1909, pp. 51-53; Rathmann, 1984, pp. 72-75; Rudersdorf, 2009). It was only after the Swedes recaptured and retained Leipzig in 1642 that a degree of stability allowed the university at last to begin recovering (Zirr, 2009, 2010, 2011). 
Confessionally, Viadrina in Frankfurt an der Oder was something of an anomaly: a Catholic foundation, tardily Lutheranized, and then subjected to a Reformed ruler since 1613 without undergoing a 'second Reformation' (Nischan, 1994). Although it escaped the drastic fate of the Reformed institutions further south, its wartime experience was far from happy. As Figure 4.9 shows, it suffered an early collapse in the late 1620s parallel to Helmstedt's. Unlike the Guelf university, however, its recovery in the early 1630s was aborted: it had to wait for the final decade of the war to make a long and very partial recovery, and its wildly oscillating matriculation rates nevertheless indicate perhaps the most tormented history of any Germany university during the war. As a rare crossing point on the Oder, Frankfurt controlled movement east and west. Only a few kilometers down-river from the northernmost point in Silesia, it also marked the border separating the Habsburg-dominated south from the Protestant north. Add to this the awkward position of Brandenburg as a whole between the Habsburg lands to the south-east and the theatre of the Danish campaigns and Swedish landings to the north and west and the source of Frankfurt's troubles begins to become apparent. On 26 June 1626, imperial troops, moving northward in force against Denmark and her allies, took control of the city and admissions to the university dropped immediately by 80 percent (Schultze, 1964, p. 223). Scarcely had the university recovered in 1628-1629 than Gustavus Adolphus took up positions in Pomerania, Tilly responded by strengthening his garrisons at the main Oder crossing-points (p. 241), and matriculations in Frankfurt fell sharply again in 1630. The arrival of the Swedes from Stralsund down the west bank of the Oder only made matters worse. With the approach of the enemy, the imperial field-marshall, Tieffenbach, burned the city's suburbs and withdrew into freshly prepared defenses. On 13 April 1631, after intense bombardment of its defenses from the heights to one side, the city was stormed in the first main siege of the Swedish king's German campaign. The savagery of the sack was not confined to the slaughter of the imperial garrison but extended to the 'persons and property of the burgers' and to the 'seals, ornaments and maces' of the university'. ${ }^{11}$ Again numbers bounced back, only to sink again as Wallenstein's troops retook possession of the city in 1633 (Schultze, 1964, pp. 252-253). Finally, after the failure of the Peace of Prague, Brandenburg was repeatedly fought over by Swedish and imperial armies, to the great devastation of cities and countryside alike, until the young elector Friedrich Wilhelm finally broke with the emperor and allied with Sweden on 24 July 1641, for more effective protection (Schultze, 1964, pp. 261-294; Parker, 1984, pp. 165, 168). During the years of greatest disruption (1636-1640), the university admitted only 397 students-less than one-fifth of its pre-war peak in the quinquennium $1614-1618 .{ }^{12}$ All told, this biconfessional institution can be

\footnotetext{
${ }^{11}$ On the background situation, see Roberts, 1953-1958, Vol. 2, pp. 243, 261, 481; for details, see Zopf, 1927.

${ }^{12}$ These vicissitudes are little evident in Günter Mühlpfordt's (1983) sanguine survey (pp. 47-53).
} 
regarded both as the most fortunate of the Reformed universities and the least fortunate of the Lutheran ones. ${ }^{13}$

The smallest of the three Saxon universities, Jena, by contrast, fared best. After record numbers in 1620, the war began badly, thanks to Thuringia's central strategic position and the lack of strong, consolidated political authority with which to repel plundering troops. The establishment of the Swedish military chancellery in Erfurt temporarily halted the decline; but Thuringian participation in the Peace of Prague exposed the region to years of Swedish reprisals after 1635. The leading theology professor, Johann Gerhard, fled Jena that year to escape imprisonment by the Swedes for supporting the Peace; in 1636, the Swedes thoroughly sacked his farmlands in Roßlau and in 1637 imperial forces plundered his house in Jena as well. Yet in conditions of such general misery, Jena nevertheless experienced relative good fortune. Even during its worst quinquennium, matriculations were nearly half the level of their peak, and the final armistice inaugurated a period of unprecedented growth (Richter, 2011, pp. 49-51; Steinmetz, 1958, Vol. 1, pp. 63-71).

The main exception within this cluster of universities was Erfurt, a unique institution before the war, which experienced a unique fate during it. A thriving institution in medieval times, Erfurt had suffered since the Reformation due to its anomalous situation: although theoretically subordinate to the elector-archbishop of Mainz, the city and its university were predominantly Lutheran. A chair for evangelical theology had existed there since 1566 and its Catholic equivalent had lapsed altogether between 1600 and 1627. Gustavus Adolphus therefore received a rapturous reception from the Protestant population upon entering the city on 2 October 1631: bells rang, the populace cheered, and the civic council invited him finally to reform the university entirely. The king and (after his death) his chancellor responded with lavish new endowments of secularized ecclesiastical lands, invitations to four prestigious Lutheran professors to join the theological faculty, a new set of statues, and up-dated methods of instruction which were to culminate in a botanical garden and an anatomical theatre. Matriculations (dented a few years earlier by an outbreak of plague) peaked in excess of 150 in 1633 . The Swedish disaster at Nördlingen and Saxony's defection to the imperial camp after the Peace of Prague upset these grandiose plans and briefly reinstated the status quo of 1627; but the Swedes regained the city in 1636 and retained it until the end of the war. Although the university can hardly be said to have thrived, its figures during the war document, on balance, only the gentlest decline (see Bock, 1908, pp. 62-67; Märker, 1993, pp. 62-97; Pelizaeus, 2005; Richter, 2011, pp. 51-54; Weiß, 2008).

The wartime fortunes of these eight Lutheran institutions show a close family resemblance: all suffered a collapse in enrolments during the middle years of the war (least dramatic in the case of tiny Erfurt, most precipitous in the giant Saxon

\footnotetext{
${ }^{13}$ Notker Hammerstein has argued that the destruction of Heidelberg 'allowed for the development of Frankfurt on the Oder as a brilliant alternative'; but it is difficult to see how this judgement applies to the wartime period itself. See Hammerstein (1986-1987, p. 120, citing Hammerstein, 1972).
} 


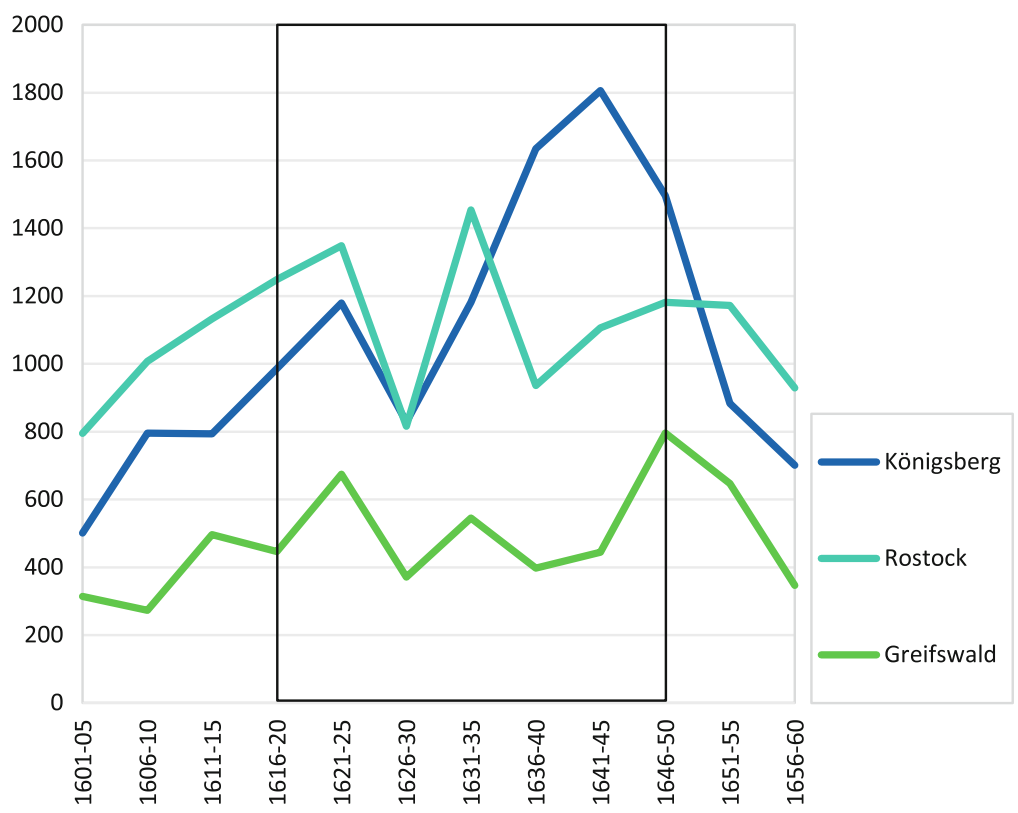

Fig. 4.10 Lutheran universities on the southern shores of the Baltic. Source: Data from Eulenburg (1904). Design by author.

universities), and all but two (Helmstedt and Altdorf) reached their nadir during the latter 1630s and experienced little recovery until the very last years of the war. Far to the north, however, three Lutheran universities followed a different rhythm: all three grew strongly in the early years of the war, suffered their worst setbacks early, recovered quickly, and experienced positive growth over the war as a whole. All three were located on the Baltic (Fig. 4.10).

The humblest of the three- both in pre-war size and in wartime prosperity —was Greifswald. Her surge in the first years of the war-from 50 to 100 student enrolments on average-was proportionately the strongest of the three; but her fall in November 1628 was more drastic. Greifswald's occupation by imperial troops was longer even than the other much abused Pomeranian cities, and the commander during most of this period, Ludovico Francesco Perusio of Malta, was described in the university's album as an 'incarnatus diabolus'. This reputation derived, however, not from suppression the city's Lutheranism but from his uncompromising measures in defending the city from the armies of Gustavus Adolphus, who landed in Pomerania not far from Greifswald in July 1630. Despite these efforts, Greifswald was the first German university city to fall to the Swedes, almost a year later, in June 1631. The sharp recovery which followed was undermined by the return of large armies to Pomerania in 1637-1638, when, as rector Balthasar Rhau complained in the register, a deluge of rustic refugees from the miseries outside the city walls ruined both the university's rural income and the living conditions of students and professors alike. From 1639, however, the Swedes, now ruled by Queen Christina, 
began to invest in the university which they successfully solicited in the protracted negotiations for peace and integrated into the Swedish network of educational institutions throughout the Baltic. Greifswald ended the war with an unprecedented surge in enrolments to around 210 students. However modest her absolute numbers, she attracted 50 percent more students during the war than in the thirty-year periods before and after it (Kosegarten, 1986, pp. 237-256; Langer, 2011). ${ }^{14}$

Rostock's university was twice the size of Greifswald's, and its fortunes tracked those of its Pomeranian neighbor on a grander scale. Throughout the early years of the war, Rostock enrolments climbed steadily to over 200 per year, despite an outbreak of plague in 1624; but between the arrival of imperial troops in Mecklenburg early in 1627 and their capture of Rostock in October 1628, matriculations crashed by four-fifths. The importance of this Hanseatic port to Wallenstein's plans to build an imperial navy inclined him to treat the city more liberally than many (Heidorn, Heitz, Kalisch, Olechnowitz, \& Seemann, 1969, Vol. 1, pp. 57-59; Stieda, 1917), and university enrolments began to recover until a new and unexpected danger emerged. On 22 January 1631, the imperial commander in Rostock, Heinrich Ludwig von Hatzfeld, was murdered in his apartments, and the culprit was quickly identified as a member of the university - a licentiate in theology named Jacob Barmeyer. Four days of inquisition under torture and strenuous assertions of loyalty from the university established, however, that the young divine had acted without accomplices; so the commander's successor satisfied the need for exemplary retribution with a most agonizing and protracted public execution and hung the theologian's four quarters over the gates of a city which had narrowly escaped a punitive sack. Further good fortune followed at the end of the year: as Rostock prepared for a long and bitter Swedish siege, the unexpected news arrived of Tilly's defeat at Breitenfeld, and on 6 October 1631 the demoralized imperial garrison capitulated without resistance rather than face the full wrath of the Swedes (Krabbe, 1863/1994, pp. 83-84, 105-125, 157-170; Roberts, 1953-1958, Vol. 2, pp. 516-517).

For the university, the worst of the war was already over. In the following six years-precisely the period in which warfare began to disrupt the more populous universities in Saxony and the south-Rostock recorded the highest entrance figures in her early history, not even surpassed in the nineteenth century; and in three of these years - 1632, 1633 and 1635-she enjoyed the highest matriculation rates of any German university. Most of these students had travelled some distance to Rostock. The percentage of native Mecklenburgers in Rostock fell from almost one-half in 1630 to scarcely one-quarter in 1635 and under one-fifth in 1640. The Scandinavians who had previously constituted as much as one fifth of Rostock's students stayed away; but in their place students arrived in unprecedented numbers from lower Saxony, Brandenburg, Prussia, the Baltic countries, and other regions as

\footnotetext{
${ }^{14}$ On the Swedish phase, see the basic study by Ivar Seth (1956), and more recent literature including Langer (2008)
} 
far away as Transylvania. ${ }^{15}$ From a university which provided a landfall for Scandinavians visiting Germany, Rostock was briefly transformed into a northern refuge for Germans themselves. Even after imperial forces regained the city in 1637, letters exempting Rostock from quartering and other burdens were consistently implemented by the mild regime of Wilhelm von Calchheim (alias Lohausen) and numbers recovered strongly. All in all, although her intake fluctuated dramatically, Rostock too had a good war: between 1619 and 1648, Mecklenburg's university recorded about 20 percent more matriculations that in the thirty years before the war and 50 percent more than in the thirty years after it.

The clearest instance of a Lutheran university profiting from the demise of its German counterparts, however, fell far outside the boundaries of the Holy Roman Empire itself, although not outside the sphere of imperial politics. Königsberg, the capital of the duchy of Prussia, was ruled by the Elector and Margrave of Brandenburg as a fief of the Polish king. The city felt the shock of the Swedes' arrival even before their entry into the German war: at the start of the Polish-Swedish War in May 1626, Gustavus Adolphus landed in Pillau, a peninsula scarcely one day's march from the Prussian city. But the Swedish king had recently married the sister of the Prussian duke, Georg Wilhelm of Hohenzollern, whose early and unconditional promise of neutrality, backed up by the city's formidable defenses, averted a Swedish siege. By the time the Swedes king arrived in Germany four years later, Königsberg's recovery was well underway; and when disaster engulfed the Saxon universities in 1636, students from across the Lutheran world began seeking the safety which its distance from the Empire provided. In August 1638, Georg Wilhelm did the same, transferring his entire court from Berlin to the Baltic city to escape the chaos engulfing Brandenburg. For a decade toward the end of the war, this provincial Landesuniversität was transformed into one of the largest and most cosmopolitan university in central Europe. During 1636, 1638, 1641, 1642, 1644, and 1646, the easternmost major university in Europe also attracted more students than any other east of the Rhine (Eulenburg, 1904, pp. 84-85; Lehmann, 1929; Roberts, 1953-1958, Vol. 1, pp. 320, 322, 325-326, 338-340; von Selle, 1956, pp. 78-79). ${ }^{16}$

Königsberg therefore highlights a very important feature of the academic geography of northern Europe in this period: the effects of the Thirty Years' War on academic populations were not confined to the Holy Roman Empire. As already noted, the huge surge in Cracow's population during the 1630s is a dramatic evidence of this feature in the Catholic world. Königsberg provides evidence that something similar was at work in the Lutheran world as well. Part III of this paper will return to consider the Lutheran and Reformed manifestations of this phenomenon in more detail. Before doing so, however, a summary of the patterns evident within the Empire is in order.

\footnotetext{
${ }^{15}$ Analyzed exhaustively in Asche (2000, pp. 62-63, 170-171, 177-178, 210-211, 213-215, 535). See also the summary in Asche (1995, pp. 141-162) and Helk (1987, p. 42).

${ }^{16}$ While students from Prussia enrolled in roughly the same numbers as before the war, their proportion of the student body dropped to one-third as the number of Pommeranians doubled, large contingents arrived from Schleswig-Holstein, Mecklenburg, Braunschweig and especially Silesia, and smaller groups travelled from as far away as Austria, Hungary and Transylvania as well as the Baltic lands.
} 


\section{Regions Compared}

The data set studied so far is by no means huge: sixty years of annual matriculation figures plus the tally of 12 quinquennial figures for each of 29 universities is only 2160 data points. Yet the complexity of this landscape is such that we need to aggregate these figures by region and confession to gain a clear sense of the overall patterns. In order to examine the relative growth or decline of different clusters of universities, the following two graphs use the pre-war size of each university as a baseline. More specifically, they express the aggregate matriculations of each cluster of universities as a percentage of their level during the five-year period 1616-1620. Matriculation levels below the 100 percent line are smaller than they were in 1616-1620, while those above the line are larger. These graphs do not, in other words, express the absolute size of these clusters relative to one another. Instead, they chart the growth and decline of each cluster relative to its size during the fiveyear period prior to the outbreak of large-scale war.

Figure 4.11 distinguishes the four regions whose wartime trajectories are plotted in Figure 4.12. The aim is not to divide the Empire into four equal parts but to distinguish four groups which shared similar wartime experiences. The three Catholic universities in the smallest cluster south of the Danube (the southeast quarter) share an experience strikingly different from the largest, multiconfessional cluster of twelve universities in the German lands south of the Main (the southwest). The eight

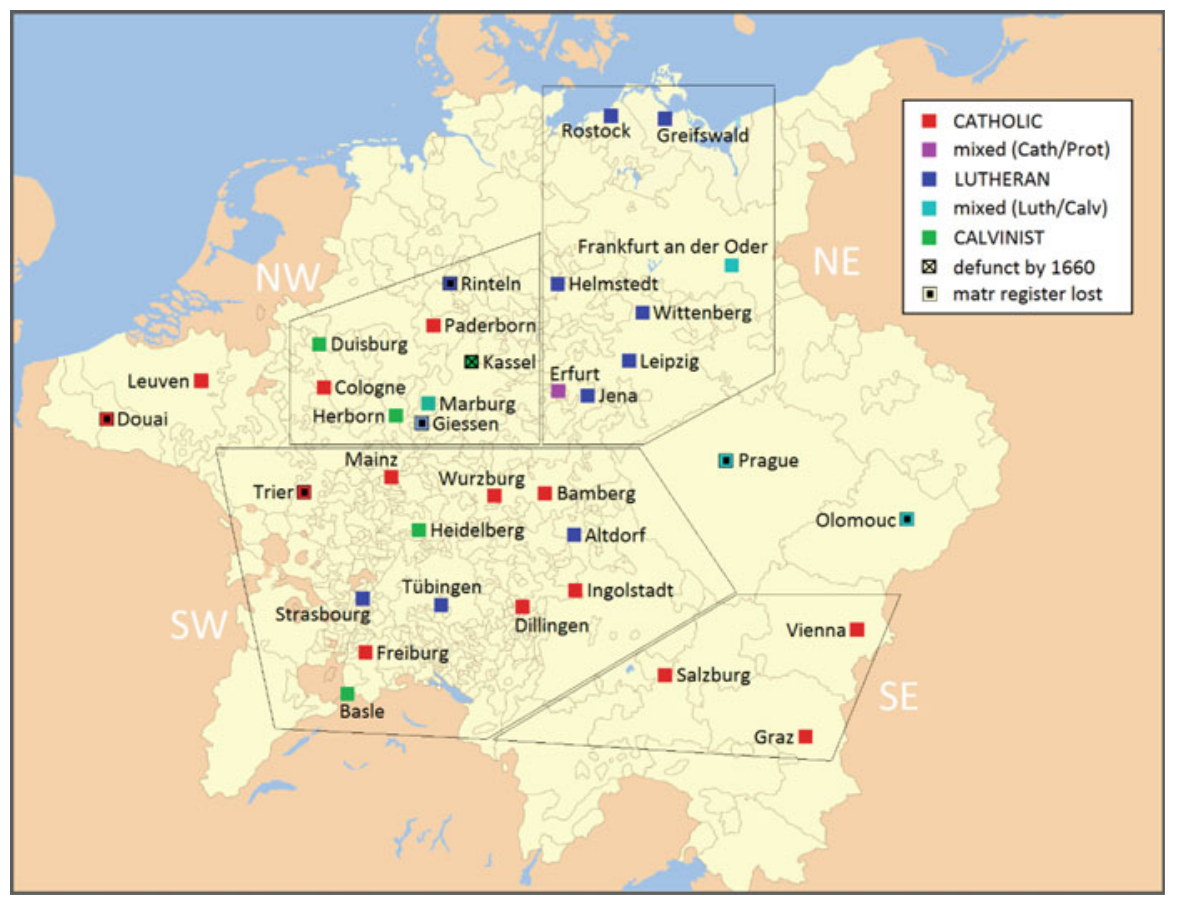

Fig. 4.11 Universities in the Holy Roman Empire, 1600-1660.

Source: Design by author. Data from Frijhoff (1996). 


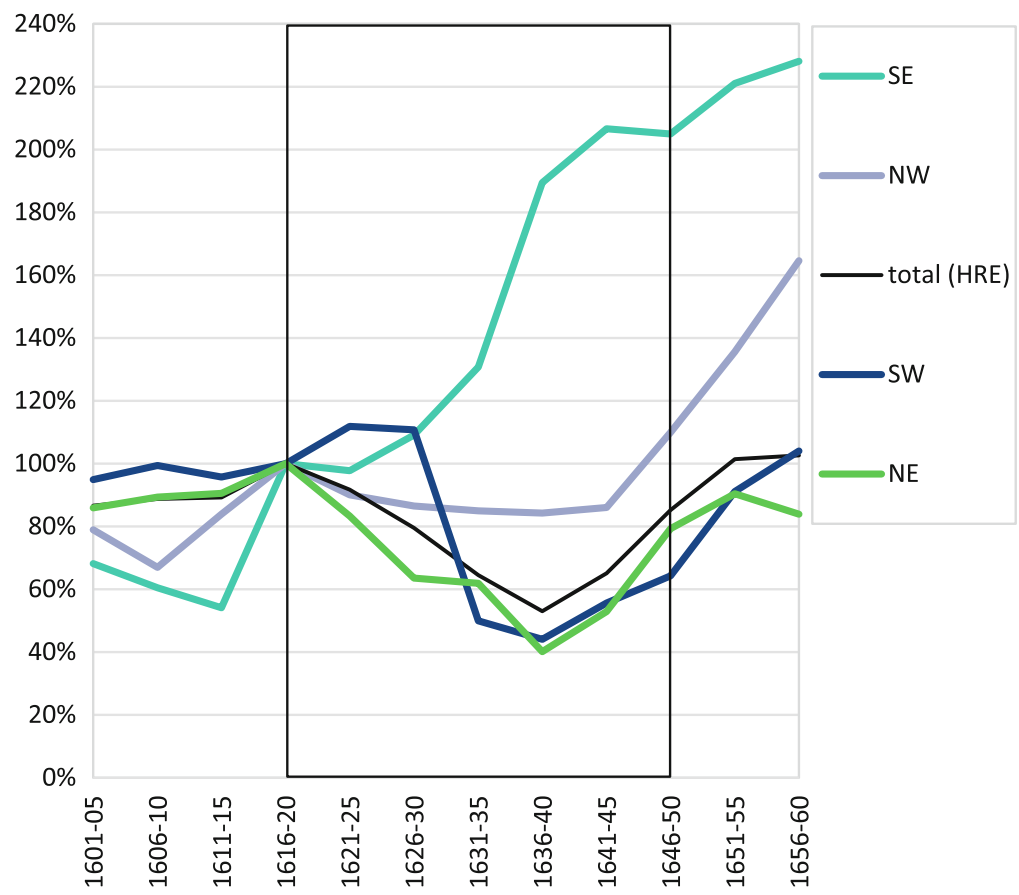

Fig. 4.12 Four quarters of the Holy Roman Empire compared. Quinquennial percentages of matriculations in $1616-1620$.

Source: Data from Andritsch (1977-1980), Eulenburg (1904), Falckenhainer (1893), Gall \& Paulhart (1974), Redlich (1933), Schillings (1962-1963), Wachernagel (1951-1980). Design by author.

mostly large and overwhelmingly Lutheran universities east of the Weser (the northeast quarter) can also be usefully distinguished from the eight institutions of all three main confessions west of the Weser and north of the Main (in the northwest) which are mostly small and patchily documented.

The Spanish Netherlands are excluded from these composite graphs, not because they were immune to the effects of war, but because their patterns of academic mobility and military conflict were distinct from those east of the Rhine. The FrancoSpanish War drastically undermined Douai and probably caused both the gradual rise and the major fluctuations in Leuven's matriculation rate after 1635. It would be highly misleading, however, to include the documented growth of Leuven in overall confessional and regional calculations while excluding the undocumented but probably much greater decline of Douai. Moreover, this localized reshaping of Leuven's catchment area is a development quite separate from the far larger disruptions to the east, which transformed patterns of academic migration throughout northern, central, and east-central Europe. Finally, there is the problem of Leuven's huge size. At the 
height of the war, Leuven matriculated more students than all the German Catholic universities put together; so its regionally-driven experience would reshape the graphs for Catholic and northwestern universities in ways not directly linked to the central European war. In short, composite graphs are more representative of the general impact of the Thirty Years' War on the Empire's universities if Leuven's data are excluded from Figures 4.12 and 4.13, and commentary on them are confined to the notes.

The most protected of these four unequal quarters, predictably, is the small southeastern cluster of Vienna, Graz, and Salzburg. During the first years of the war, their extant matriculation figures record only the tiniest contraction. After the Swedish arrival, their combined rate of matriculation skyrocketed, doubling in a decade and remaining high for at least two more. If the missing matriculation figures could be added for Salzburg between its opening in 1622 and 1639, when the surviving register begins, the resulting line would probably record even more continuous growth, beginning after 1612-1615 (when Graz's numbers temporarily dipped), receiving fresh impetus in 1622 (when Salzburg opened), and continuing in the early 1630 s (immediately after the Swedish invasion to the north). In this region, therefore, the war only appears to have reinforced a sustained period of impressive growth which began well before and ended well after the conflict itself. The border between this uniquely fortunate southwestern zone and the war-torn area to the north and west was marked-geographically and militarily-by the heavily fortified Ingolstadt: as a glance back at Figure 4.6 suggests, Ingolstadt shared the fates of the other Catholic universities in the path of the Swedes but departed from the regional pattern in its partial recovery in the latter 1630s.

Diagonally opposite, the multiconfessional northwestern corner of Empire had a more varied experience and one far less confidently depicted by the surviving data. The reliable series, graphed in Figure 4.12, chart a remarkably continuous period of stability throughout the wartime period. Early in the conflict, the decline of tiny Herborn depresses the line despite the stability of the far larger Cologne. In the final years of the war, the expansion of Cologne, the partial recovery of Herborn, and the availability of matriculation figures for Paderborn begin a pronounced period of growth, to which the new university in Duisburg made a modest contribution after 1655 (Geuenich \& Hantsche, 2007). ${ }^{17}$

Unfortunately, missing data for most of the institutions in this region undermines the reliability of these results. On the one hand, the opening of new universities in Paderborn (1616) and Rinteln (1620) would presumably have contributed modest growth in the early years of the war; but this growth cannot be graphed because Rinteln's register is missing completely and Paderborn's is lost before 1637. On the

\footnotetext{
${ }^{17} \mathrm{~A}$ database of the matriculation register is in preparation: https://www.uni-due.de/ub/archiv/ universitaetsmatrikel.shtml.
} 
other hand, the tumultuously interconnected histories of Marburg, Giessen, and Kassel would have disrupted this impression of stability and may well have depressed the overall trend; ${ }^{18}$ but since Giessen's matriculation register is lost completely and Marburg's is missing from 1638 to 1652, the patchy surviving figures for Marburg and Kassel cannot contribute to a coherent general assessment and have been excluded from this graph. Since the growth of Paderborn and Rinteln and the disruption of the Hessian universities probably counteracted one another to some degree, the overall trend indicated on the graph may nevertheless be a very rough guide to the fortunes of the universities in this region. Further west, the gentle rise of Leuven was probably caused in part by the far more dramatic decline of Douai. ${ }^{19}$ What is certain is that the well-documented Catholic universities in this region-Cologne, Paderborn, and also Leuven — can be sharply distinguished from the other German Catholic universities: while they did not benefit from the war to the degree of the three southeastern universities, they were fall less disrupted than their nearer Catholic neighbors. Helmstedt marks the eastern boundary of this comparatively protected group: as a return to Figure 4.8 suggests, its dramatic decline parallels the territories to the east, but its early partial recovery may reflect the more sheltered conditions to the west.

The relative safe havens to the far southeast and northwest contrasted sharply with the broad military corridor running diagonally from northeast to southwest. Most dramatically affected by the war was the dense population of relatively small universities of all three main confessions in the southwest. ${ }^{20}$ Here, a far more complete dataset produces a far more coherent picture. Buoyed by positive growth in Freiburg and Würzburg and especially by the foundation of Strasbourg and Altdorf, the southern universities expanded by twelve percent in the first years of the war, despite the collapse of Heidelberg. The arrival of the Swedes then cut matriculations there by over half during the 1630s. The continuing conflict in the region allowed only a tepid recovery before the end of the conflict, after which enrolments bounced back to pre-war levels, bolstered slightly by the foundation of Bamberg.

The experience of the equally well-documented northeastern quadrant of the Empire was less dramatic but more devastating on the whole. In this overwhelmingly

\footnotetext{
${ }^{18}$ The Calvinist takeover of Marburg in 1605 prompted the establishment of Giessen in 1607; the Luther reconquest of Marburg in 1624 led to the closing of Giessen, followed by the establishment of Kassel in 1633; and the recovery of Marburg by the Reformed branch of the house of Hesse in 1652 provoked the closure of Kassel and the reopening of Giessen.

${ }^{19}$ Adding the Leuven's figures to those for Cologne, Herborn, Paderborn and Duisburg would preserve the sense of relative stability, while flattening the long-term trend, which would gradually rise from a low of 87 percent of pre-war levels in the early 1630s to a high of 126 percent in 1660 .

${ }^{20}$ Trier is missing from this figure because its matriculation register does not survive. Basle is included because it was closely integrated into the Reformed academic system and clearly affected by the war in the southwestern corner of the Empire.
} 
Lutheran region, the impact of war was felt in a differentiated fashion, as the main theatre shifted from place to place. Helmstedt suffered worst during the Lower Saxon phase of the war; Rostock and Greifswald during the Swedish landing; the giant Saxon universities after the failure of the Peace of Prague; and Frankfurt an der Oder was hammered twice: once in the latter 1620s and again in the latter 1630s. Overall, the modest gains experienced by Rostock and Greifswald were eclipsed by the massive losses of the larger universities further south. Due to the huge size of these northeastern universities, their aggregated matriculations closely track the trajectory of the Empire as a whole. This means that the decline of this region was far more gradual than that of the southeast. Its recovery in the final years of the war was more rapid but also only partial: unlike the other three quadrants, pre-war levels were never quite regained in this period.

The disparity of these four regions is considerable. Taking again the period $1616-1620$ as the standard, the average annual rate of matriculation between 1621 and 1650 rose in the three southeastern universities by over one half (56 percent), dropped in the northwestern institutions for which we have reliable data by ten percent, ${ }^{21}$ fell in the war-torn southwest by over one quarter (27 percent), and declined in the larger northeastern quadrant by over one third (36 percent).

\section{Confessions Compared}

An analogous graph reveals the diverse experiences of the three main confessions, although this also needs to be interpreted with care (Fig. 4.13). The collapse of Reformed matriculations (not counting the bi-confessional Frankfurt an der Oder but including Basle) was immediate and its effects widespread and long-lasting. With the loss of Heidelberg in 1622 and Marburg in 1624 and the disruption of the routes which carried students to Herborn and Basle, Reformed student numbers fell by nearly four fifths, and they remained at this very low level for a quarter century, despite the foundation of Kassel in 1633. A sharp recovery followed the reopening of Heidelberg, the restoration of Marburg, and the foundation of Duisburg in 1652; but even by 1660 the Reformed figures had only recovered two thirds of their pre-war strength. If Basle-just outside the effective borders of the Empire-is removed from the equation, the situation is even bleaker: in the quarter century between the loss of Marburg and the end of the war, matriculations in the Reformed universities within Germany fell to scarcely one tenth of their pre-war level.

A stark contrast is provided by the trajectory of Catholic enrolments within the Empire. Rock steady within the first dozen years of the conflict, they were collectively cut by one third in the years immediately following the Swedish invasion-the

\footnotetext{
${ }^{21}$ If Leuven is included, the loss is only six percent.
} 


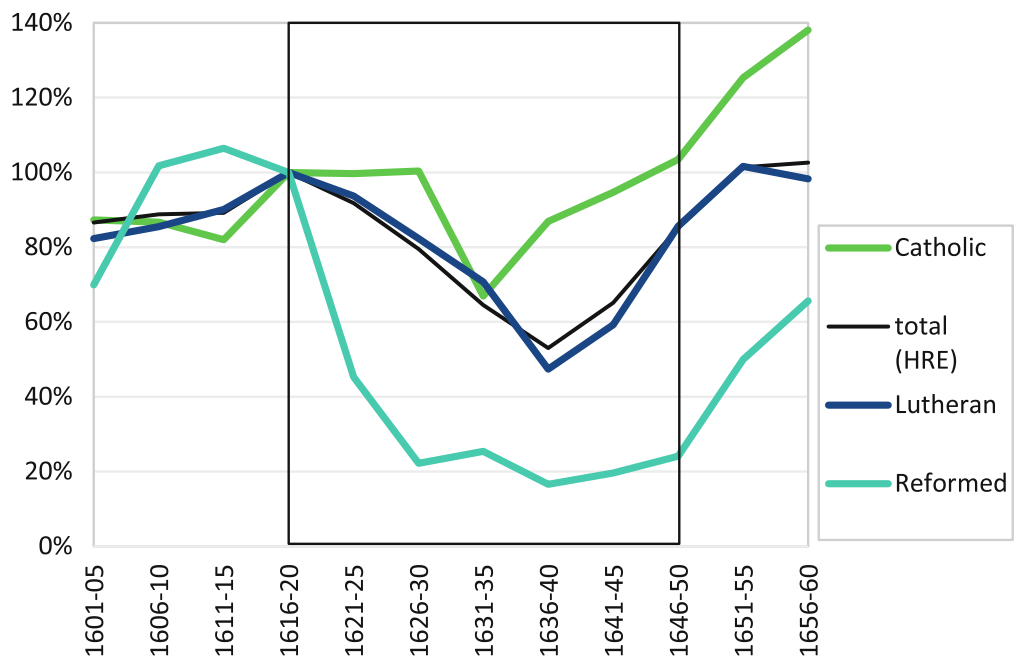

Fig. 4.13 Three main confessions within the Holy Roman Empire compared. Quinquennial percentages of matriculations in 1616-1620.

Source: Data from Andritsch (1977-1980), Eulenburg (1904), Falckenhainer (1893), Gall \& Paulhart (1974), Redlich (1933), Schillings (1962-1963), Wachernagel (1951-1980). Design by author.

only period in which the Catholic universities reflected the imperial experience as a whole. Thereafter, fortunes divided sharply. Catholic institutions within the territory of modern Germany recovered very slowly until the end of the war, but returned to full strength rapidly after its conclusion. Within the Empire as a whole, however, these losses were compensated by gains to the southeast. Finishing the war marginally stronger than they began it, the Catholic figures for the Empire a whole then rose sharply during in the first post-war decade to a level 38 percent higher than their status ante bellum. ${ }^{22}$

The Lutheran figures again shadow the curve of the Empire as a whole, due to their huge size and an experience intermediate between the other two main confessions. After a gradually accelerating decline in enrolments from the start of the conflict, Lutheran matriculations were cut to less than half of pre-war levels by 1640; but they recovered slightly more rapidly than they declined, fully regaining their pre-wars levels shortly after the conclusion of the war. ${ }^{23}$

\footnotetext{
${ }^{22}$ Due to its large and relatively stable size, including Leuven flattens the curve (after 1616-1620) without transforming its overall shape: the nadir in 1631-1635 rises from $67 \%$ to $73 \%$, and the post-war high in 1656-1660 falls from 138\% to 128\%. The missing data for Douai would flatten this post-war surge still further.

${ }^{23}$ Even if the incomplete matriculations for Giessen, Marburg, and Rinteln could be included, they would make little impact on this graph, given the large size of the other Lutheran universities. The biconfessional universities-Frankfurt an der Oder from 1613 and Marburg from 1652-are excluded.
} 
Taking the period $1616-1620$ as the standard once again, the average annual rate of matriculation between 1621 and 1650 dropped in Reformed institutions within the Empire by an average of 87 percent, in Lutheran universities by 27 percent, and in Catholic universities by just 7 percent. $^{24}$

\section{Part III. Universities outside the Holy Roman Empire}

In all but two of the eleven years between 1632 and 1646, the universities east of the Rhine which enjoyed the largest enrolments were three of the five most northerly ones: Helmstedt, Rostock, and Königsberg. Of these, the university whose fortunes were most palpably enhanced by the war was Königsberg, which benefitted not only from its northerly position but, still more, from its location far outside the eastern boundary of the empire as well. When combined with the example of Cracow noted above, this finding opens a further line of inquiry. To what extent is the impact of the Thirty Years' War evident in universities and university systems outside the borders of the Empire?

There is obviously no room here for an attempt to provide a pan-European answer to this question, and the methods employed in this paper are in any case not adequate to such a task. There is no doubt that the influx of Protestant students to the two English universities was increased by the chaos in central Europe, at least until the outbreak of similar chaos in England after 1642; but the data needed to survey this influx does not yet exist. France may also register this effect: Orléan enjoyed a surge of foreign students during the war which subsided after it, and they came both from war-torn regions east of the Rhine and from Dutch students displaced from their traditional destinations in Germany (Brockliss, 1987, p. 18; Frijhoff, 1986b, p. 211; Julia \& Revel 1989, p. 67). Further study is also needed of the extent to which the great international medical university of Padua was disrupted by the alteration of academic trade routes during the wartime period. The most obvious places to look for the extra-imperial impact of the war, however, are in two geographically and culturally adjacent regions: in Lutheran Scandinavia and the Reformed Dutch Republic.

\section{Scandinavia}

Between 1620 and 1626 Gustavus Adolphus placed the Uppsala University on entirely new foundations. An independent chancellor was appointed (the

\footnotetext{
${ }^{24}$ If Basle is included, the Reformed drop rises to 74 percent. If Leuven is excluded (as in Fig. 4.13), the Catholic drop increases to 8 percent. If Frankfurt an der Oder is included as a Lutheran institutions, then the Lutheran losses rise to 29 percent.
} 
redoubtable Johan Skytte), the number of professors was more than doubled from eight to 19, the university was endowed in perpetuity with huge grants of inalienable, untaxed crown land which raised its annual revenue twelve-fold, a new charter and revised constitution were introduced, a university library founded, and new buildings erected which were to remain the principal quarters of the university for over two centuries. With the beginning of Queen Christina's personal rule in 1644, there began a second wave of activity, with a further six professorships and carefully revised statutes (Ingemarsdotter, 2011, pp. 247-250; Lindroth, 1976; Roberts, 1953-1958, Vol. 1, pp. 469-476). The renaissance in Uppsala was not, of course, such a direct result of the war as that in Königsberg, but connections between the two developments are not difficult to find. Imperial ambitions required educated officials. So did protracted involvement in the central European war. Uppsala's library was stocked almost entirely from the fruits of Sweden's campaigns in the Baltic, Germany, Poland, and Bohemia - notably with Jesuit libraries from Riga and Braunsberg and episcopal libraries from Frauenburg, Würzburg, and Mainz. The 8600 printed books and 1165 manuscripts rapidly amassed by 1640 eclipsed most university libraries on the continent, but only five of these works, it has been claimed, were Swedish. The central Europeans who filled many of the university's new chairs in this period-like the Bohemian physician Johannes Raicus who arrived in 1627 and the three Strasbourgers appointed in the 1640s-found the attractiveness of the northern university increased by the deplorable conditions at home. The same applied to a few students, but the numbers remained small: in the decade before the war only a single German inscribed his name in the matriculation register; during the war the number rose to 50 (Achelis, 1957, p. 195; Andersson, Carlsson, Sandström, Sjögren, Brenner, \& Thimon, 1900, Vol. 1; Lindroth, 1976, p. 50) (Fig. 4.14).

Another direct fruit of Sweden's conquests was the foundation of a new university in the Estonian town of Tartu (Dorpat). In November 1629, Uppsala's first

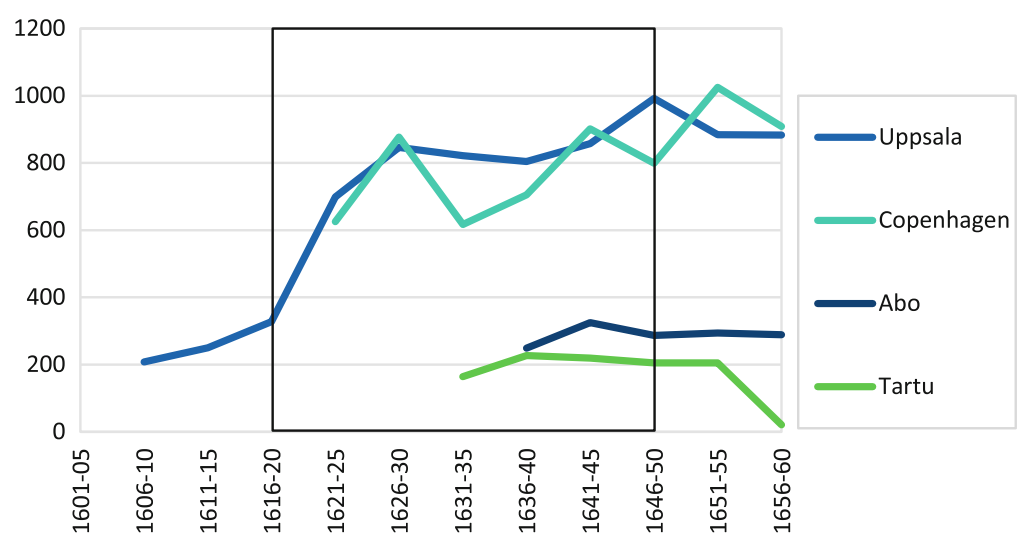

Fig. 4.14 Swedish and Danish universities.

Source: Data from Andersson, Carlsson, Sandström, Sjögren, Brenner, \& Thimon (1900), BirketSmith (1890-1912), Lagus (1889-1906), Tering (1984). Design by author. 
chancellor, Johan Skytte, was appointed governor-general of the newly conquered province of Livonia together with Ingria and Käkisalmi. Realizing the need for officers for the new administration, he immediately set about founding an academic gymnasium in Tartu which the king raised to university status in 1632. Initially the institution thrived in a modest, provincial way: some 1016 students matriculated in Tartu in its first quarter-century, the greatest number (400) from Sweden but roughly 150 from Brandenburg, Pomerania, and Saxony and wandering individuals from as far afield as England, Amsterdam, Frankfurt am Main, Austria, Hungary, Transylvania, and Moscow. Numbers dipped momentarily in 1635, due to the threat of war between Poland and Sweden, but recovered immediately and remained steady for a further two decades. It was only after the end of the central European war that serious trouble set in. The Russian siege of Tartu forced the university to transfer to Tallinn in 1656, and without solid financial foundations in its new location it wasted away: only 49 new students were entered in the decade before its closure for a quartercentury in 1665 (Tering, 1984, p. 20; see also Achelis, 1957, p. 196; Roberts, 1953-1958, Vol. 1, pp. 478-479; Siilivask, 1985, pp. 22a-35b). In 1640 Queen Christina established a royal academy in the Finnish city of Turku (Swedish: Åbo) from which the modern University of Helsinki descends (Lagus, 1889-1906, Vol. 1, p. VI) (Fig. 4.14).

While matriculations plummeted to the south and soared to the north, Copenhagen's annual intake rose gradually from the first preserved lists of 1621 to peak in 1651 at 259. The Danish king's varying fortunes in the great central European war seem to have little affected this gradual rise: numbers dropped momentarily to 69 in the year of the defeat at Lutter but reached a new high of 216 the following year which even the Wallenstein's incursion into Jutland in 1627 failed significantly to reduce. Here too it was not until war began with Sweden in 1657 that the university began to feel the direct effects of the Baltic wars of the era (Birket-Smith, 1890-1912, Vol. 1; Ellehøj, Grane, \& Hørby, 1979-1991, Vol. 1 , pp. 248, 260). Copenhagen's experience suggests that it was the direct rather than indirect impact of the war-the arrival of enemy troops on the outskirts of the city rather than the general deterioration of social and economic conditions-which caused the drastic fluctuations of matriculation rates across central Europe in this era. The impact of the Thirty Years' War is evident in Copenhagen primarily in the changing foreign composition of the university. In the years before 1618, scarcely one German matriculated annually in Copenhagen. During the entire course of the war, only one Dutchman, one Swiss, and one Pole enrolled there; but the number of Germans rose to 160 , most of them displaced between 1625 and 1630 by the DanishLower Saxon phase of the war and the chaos attending the arrive of the Swedes (Achelis, 1957, pp. 193-195, 196). 


\section{The Dutch Republic}

Placed in relation to the catastrophic disruption of central European universities generally, the collapse of Reformed universities in particular, and the flourishing of university on the shores of the Baltic, the fabled golden age of Leiden and the other Dutch universities takes on a rather different complexion. In order to appreciate the importance of this military context, we must challenge the myth-widespread not so much in specialized literature on the history of universities as in more general treatments of Holland and her golden age - that Leiden was an international attraction of the first importance virtually from the moment of her founding by William the Silent in $1575 .^{25}$ That the university in Leiden was an important, international intellectual center from very early on is not subject to dispute: from a precocious stage the presence of great scholars such as Justus Lipsius and Joseph Scaliger made it the acknowledged capital of late humanist philology. But it does not follow that the young university established itself equally quickly as a Mecca for international student pilgrims: on the contrary, its numbers were initially rather small and its international student body numerically modest. In the quarter century between its foundation in 1575 and 1600, Leiden attracted on average 100 new students per year of which over three-quarters came from the Netherlands (north and south) and only one tenth from Germany. Such figures are substantially larger than only one-quarter of the German universities in this period, and one-fifth that of the huge Saxon institutions, Leipzig and Wittenberg. The modish university of Helmstedt, founded the year before Leiden, attracted three times as many students as Leiden in its first twenty-five years and 60 percent more in the decade immediately before the war. But as Helmstedt's numbers crashed Leiden's soared. In the quarter century between 1625 and 1650, Leiden's average annual matriculation approached 450; and of these over half were foreigners and over one quarter German - an increase, in absolute terms, of ten-fold (Colenbrander, 1925, pp. 292-294; Schneppen, 1960, p. 11). ${ }^{26}$

When foreign students are distinguished from domestic ones and the latter analyzed more closely according to place of origin, the relationship between Leiden's glory and central Europe's misery becomes clearer still-even when relying here on H. T. Colenbrander's relatively crude presentation of the data in terms of twenty-five-year periods. ${ }^{27}$ Matriculations in Leiden by Dutch students peaked in the third quarter of the seventeenth century; those from Western Europe in the fourth. Matriculations from Germany, however-which constituted half or more of the foreign total throughout the seventeenth century-rose five-fold in the first

\footnotetext{
${ }^{25}$ A claim already firmly established in Diderot and le Rond d'Alembert (1751-1772, Vol. 9, p. 451): "Il semble que tous les hommes célèbres dans la république des Lettres s'y sont rendus pout faire fleurir, depuis son établissement [emphasis added] jusqu'à nos jours".

${ }^{26}$ Franeker - the next oldest and largest Dutch university in this period-followed a very similar trajectory, though with merely one quarter of Leiden's absolute numbers (Bots \& Frijhoff, 1985).

${ }^{27} \mathrm{~A}$ more nuanced picture will emerge when the digitised matriculation register becomes available which Martine Zoeteman (2011) assembled for her doctoral dissertation.
} 


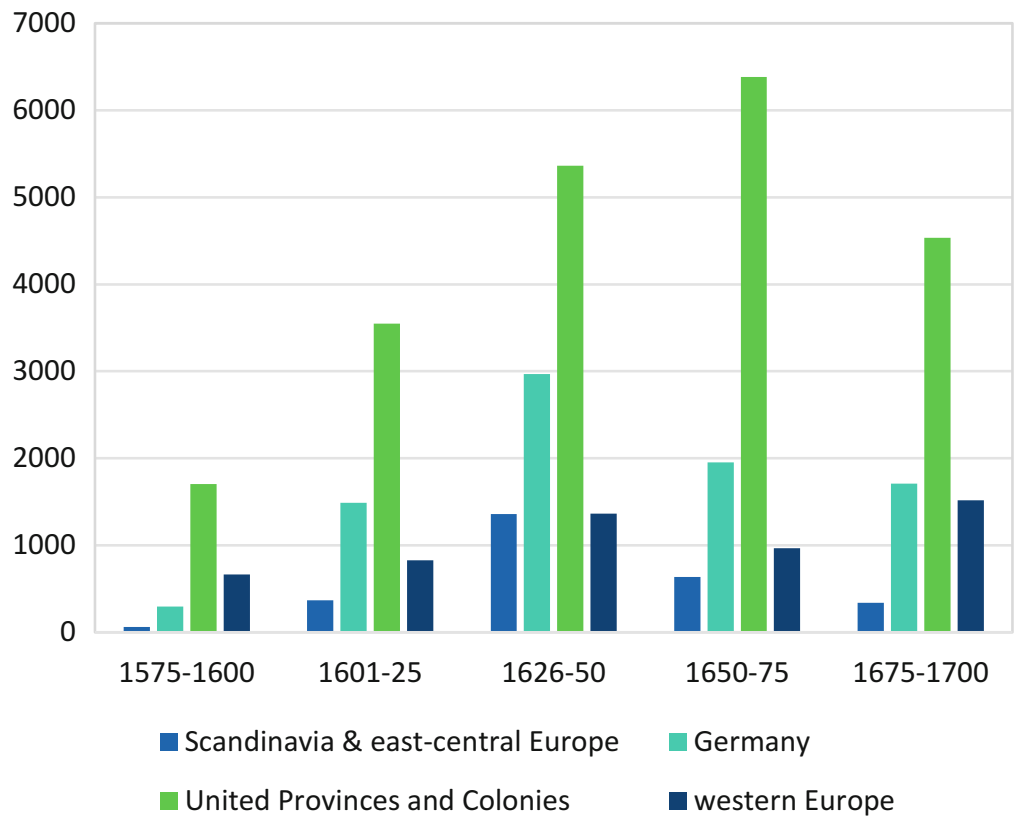

Fig. 4.15 Leiden: Major Areas of Recruitment, 1575-1700. Source: Data from Colenbrander (1925). Design by author.

quarter of the seventeenth century, peaked at double that level in the second, and then fell by one third in the quarter-century after the war. ${ }^{28}$ The main German Protestant cities and territories which sent students in large numbers to Leiden likewise sent most in the period 1626-1650 (Colenbrander, 1925, pp. 283-284, 292-294) (Fig. 4.15). ${ }^{29}$

A closer look at individual German territories establishes the point more precisely. In the decade before the sack of Heidelberg only 25 students from the Palatinate matriculated in Dutch universities (versus over three times that many

\footnotetext{
${ }^{28}$ Figures from Colenbrander (1925). The surge of German students into Leiden is even more impressive considering that a disproportionate share of the column for 1601-1625 represents students who matriculated in 1618-1625. The same applies, to a lesser degree, for students from Scandinavia and east-central Europe. The western European figures for 1575-1625 are inflated, on the other hand, by students born in the southern Low Countries who immigrated with their parents to the north and who were denizens of the north when they matriculated in Leiden.

${ }^{29}$ These figures include Emden (with 53 matriculations in this period), Westphalia (with 95), Wezel (41), Cologne (43), Hamburg (94), Holstein (94), Braunschweig (49), Brandenburg (75), Prussia (159), Danzig (87), Silesia (174), Frankfurt am Main (46), the Palatinate (90), and Basle (24). Two notable exceptions are Nuremberg, home to many Dutch commercial refugees, which peaked in the first quarter-century with 55, and Bremen, which did not begin to send its sons in large numbers to the Dutch universities until Marburg was wrested from Reformed control and Helmstedt undermined. Bremen's matriculations in Leiden did not peak until after the war was over (Prüser, 1928, pp. 245-246; Schneppen, 1960, pp. 20-22).
} 


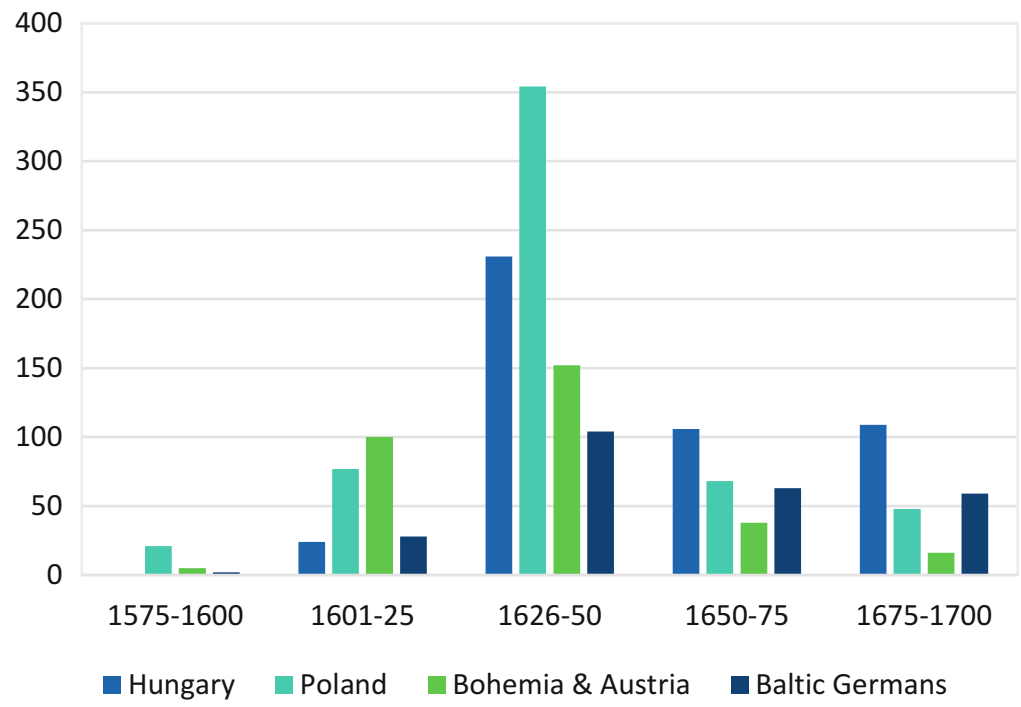

Fig. 4.16 Leiden: Matriculations from Scandinavia and east-central Europe. Source: Data from Colenbrander (1925). Design by author.

Dutch students who enrolled in Heidelberg) (de Wal, 1886). ${ }^{30}$ In the decade after 1622 the number nearly quadrupled to 97 . During the subsequent twenty years, 124 further Palatine students followed, but in the decade following the reopening of Heidelberg in 1652 the enrollment dropped again to 21 (Persijn, 1959, pp. 11-21 and Appendix). Despite the even closer links of the counts of Nassau-Dillenburg to the house of Nassau-Orange (Lademacher, 1995; Oestreich, 1960), the case of the Wetterau counties was similar. The few Nassovian students who matriculated in Dutch universities before the war were mostly members of the House of Nassau itself; numbers surged in 1623 and remained high (by their own modest standards) throughout the war (Wolf, 1935). Hessian enrollments in the United Provinces (including many Lutheran as well as Reformed students) peaked somewhat later with the nadir of German universities generally around 1638 (Wolf, 1930). Taken together, the recruitment pattern for these three German Reformed communities appears to fluctuate with the course of the war in central Germany.

Even more dramatic was the surge of students from the northern and east-central European regions, which had previously constituted the broader catchment area of the German universities, but which had sent even fewer students to Leiden before the outbreak of the war (Colenbrander, 1925, pp. 285-286, 294). In the second quarter of the seventeenth century, the number of Polish students in Germany fell by three-

\footnotetext{
${ }^{30}$ De Wal's rich data must be used cautiously, since de Wal included East Frisians, Dutch emigré families, and Germans who later emigrated to the United Provinces on his list; but a conservative listing includes 77 Dutch students in the Heidelberg register in 1612-21, despite a dramatic fall in 1620 and 1621.
} 


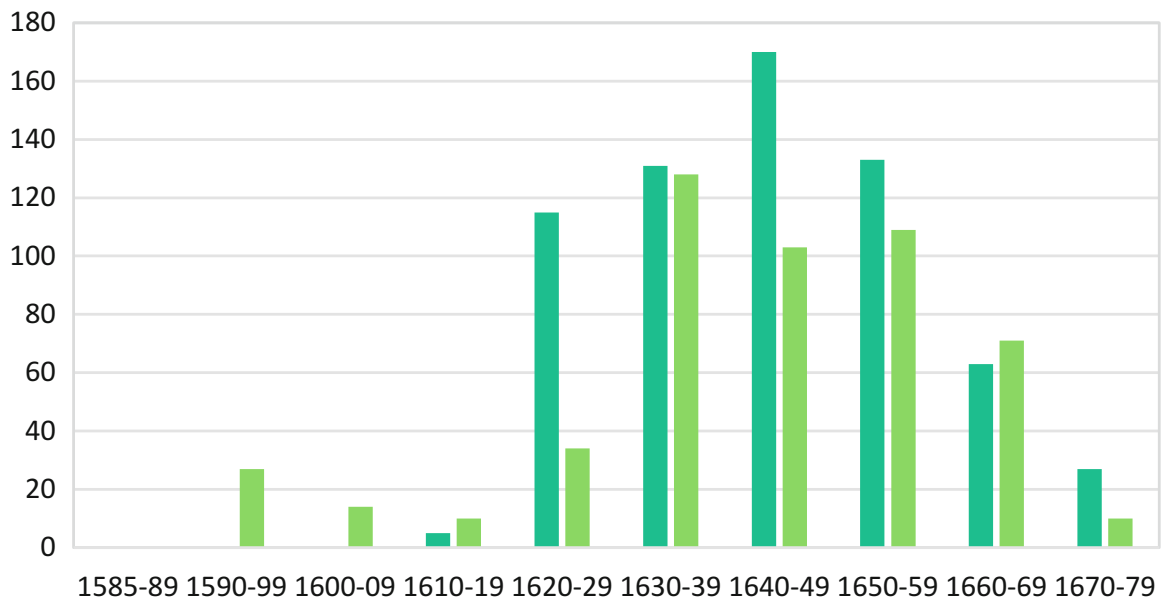

east-central Europe $\quad$ Scandinavia \& Baltic

Fig. 4.17 Franeker: Matriculations from Scandinavia and East-Central Europe. Source: Data from de Ridder-Symoens (1985). Design by author.

quarters; simultaneous the number of Poles in Leiden rose five-fold, only to drop to less than its pre-war level after $1650 .{ }^{31}$ Hungary's numbers soared ten-fold in the second quarter of the century and were then cut in half in the third. Matriculants from Austria and Bohemia both rose by one-third and then fell by 54 and 91 percent respectively. The number of Baltic Germans in Leiden grew by a multiple of four and then fell by 40 percent during the same interval (Schneppen, 1960, pp. 29-30) (Fig. 4.16).

These trends were not confined to the most populous of the Dutch universities. Franeker's experience was similar (Fockema, Sybrandus, \& Meijer, 1968; de Ridder-Symoens, 1985). The number of east-central Europeans skyrocketed with the collapse of the German Reformed institutions after 1620, peaked in the 1640s, and then declined for the next thirty years. Matriculations from Scandinavia and the Baltic more than trebled in the 1620s and then nearly quadrupled again in the 1630s, as the German Lutheran universities reached their nadir, before draining away more gradually in subsequent decades (Fig. 4.17).

Comprehensive studies of student travel from Denmark and Sweden allow an even closer correlation of German losses with Dutch gains. When the first Swede matriculated in Leiden in the early 1610 s, 40 of his countrymen were enrolling every year in German universities. In the middle two decades of the war, the tables turned dramatically: Swedish enrolments in German universities dropped to barely one-quarter of their pre-war level as inscriptions in Dutch universities climbed to

\footnotetext{
${ }^{31}$ For the German figures, see Żołądź-Strzelczyk (1996, p. 108).
} 


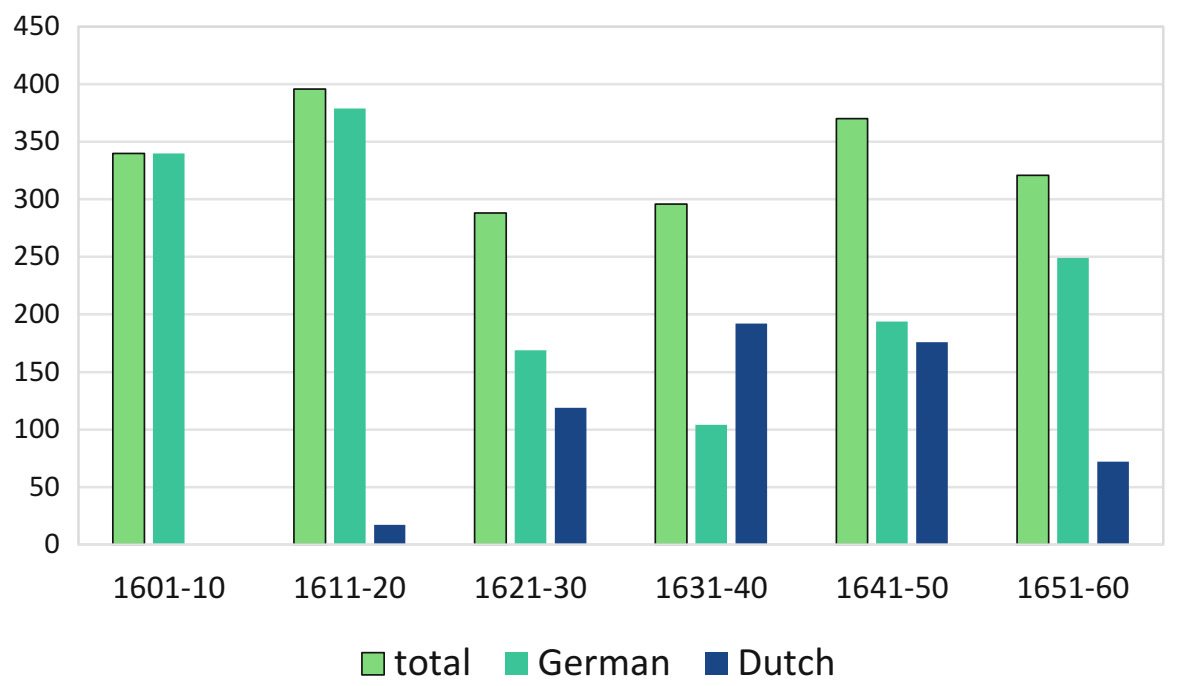

Fig. 4.18 Swedish matriculations in German and Dutch universities. Source: Data from Niléhn (1983b). Design by author.

almost twice the German level. As German universities began to recover in the latter 1640 s, the attraction of the Dutch ones fell correspondingly. Over the period 1601-60, as the majority of Swedes abroad shifted from Germany to the Netherlands and back, the total number of Swedes matriculating in these two places never varied more than 16 percent from the decennial average for this period (Niléhn, 1983a, p. 102; based on Niléhn, 1983b) (Fig. 4.18).

The Danish picture is similar. The numbers of students from Denmark-Norway in German universities mirrored the general levels of matriculations there. Attendance at Reformed institutions-representing almost one quarter of Danish matriculations in Germany in the thirty years before the outbreak of war-dropped virtually to nothing in the 1620 s and only rose slightly thereafter, primarily on the strength of Basle. Attendance at Lutheran universities fell sharply in the 1630s-with the notable exception of Königsberg, which enjoyed by far its greatest Danish intake in this decade. As Danish numbers in German universities fell, those in Dutch institutions grew nearly five fold between the prewar decade and their height in the 1630s. For the final two decades of the war Danes matriculated in Dutch universities in numbers 50 to 60 percent higher than in German ones. Aside from the fact that Denmark-Norway sent more students abroad, their main difference with the Swedish case is a more enduring attachment to the Dutch institutions: Danes were among the first northerners to visit the Dutch universities in significant numbers, and their fondness for them cooled only gradually after 1648 (Helk, 1987, pp. 42-43) (Fig. 4.19). 


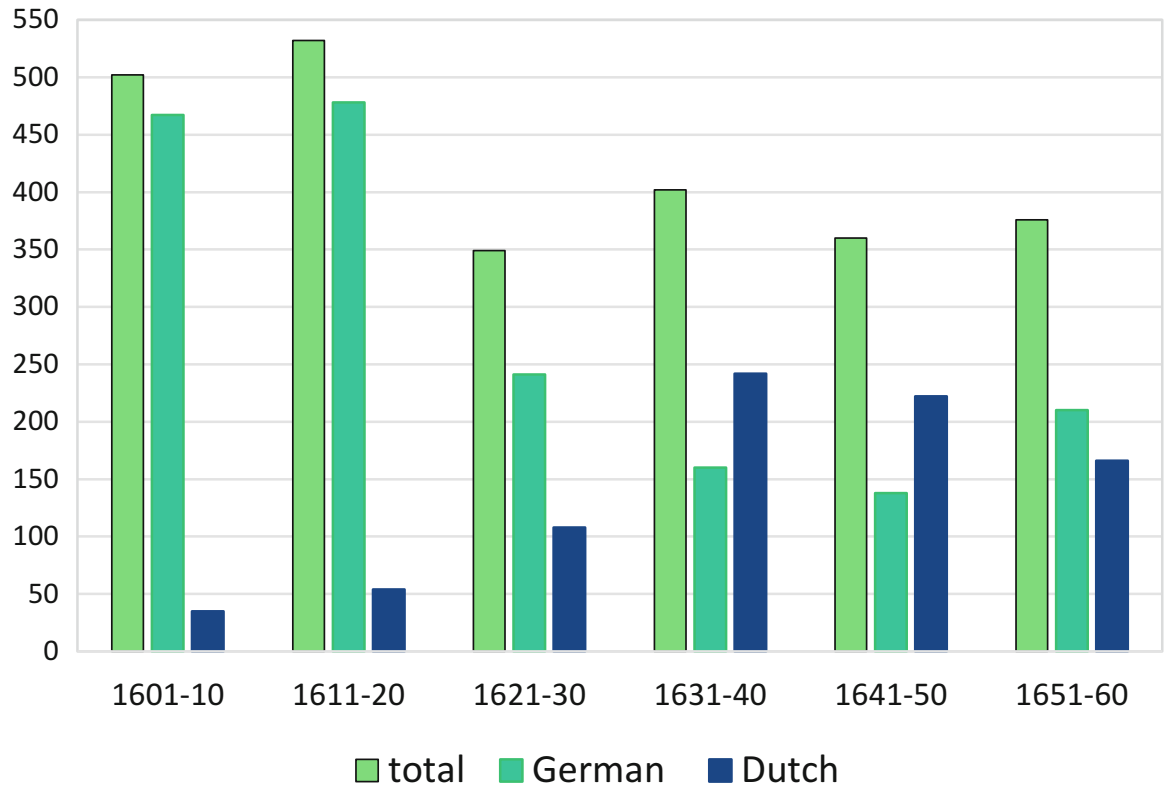

Fig. 4.19 Danish matriculations in German and Dutch universities. Source: Data from Helk (1987). Design by author.

The salient point here is not merely that the Thirty Years' War affected patterns of student migration far beyond the borders of the Empire, nor only that the destruction of the German Reformed universities helped propel the rise of the Dutch ones. The broader point is that the Dutch and German Reformed universities appear to be integrated into a single Universitätslandschaft not dissimilar to the Catholic one revealed earlier. The integration of the Catholic system, discussed above, is manifested in two main ways: on the one hand, the losses suffered by the Catholic universities in southern Germany were mostly compensated by gains to those to the southest; and on the other, even the main exception to this rule- the deep trough in Catholic matriculations within the Empire as a whole manifest in the early 1630swas mirrored by the huge spike in Cracow's recruitment between 1632 and 1636 . The Catholic universities between Leuven and Cracow therefore appear to have operated as parts of a system: when military events prevented students from studying in one part of the system, they simply transferred to another part. Although the fortunes of individual institutions and whole regions fluctuated dramatically, the population of students within the system as a whole remained remarkably stable.

The Swedish and Danish-Norwegian data suggests that something similar can be said for the Reformed university system; and this is confirmed by another view of the data. Figure 4.20 plots the aggregate fortunes of the main German Reformed universities-Heidelberg, Basle, Herborn, and Marburg — as one line, and the three oldest Dutch universities-Leiden, Franeker, and Groningen—on the other 


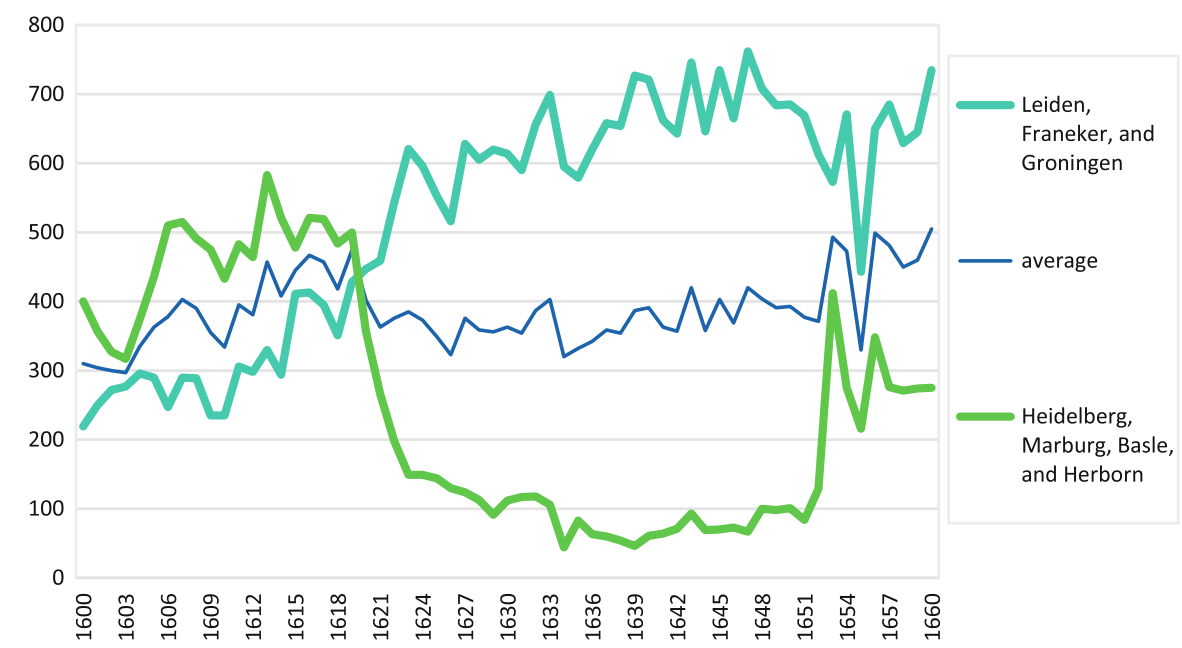

Fig. 4.20 The Reformed university system.

Source: Data from Du Rieu (1875), Eulenburg (1904), Fockema, Sybrandus, \& Meijer (1968), Historish Genootschap te Groningen (1915), Wachernagel (1951-1980). Design by author.

(du Rieu, 1875). Once again, the two lines appear roughly to mirror one another. The Dutch figures leapt by 77 percent during the first five years of the war while the German Reformed numbers were cut by over two thirds. As the German Reformed line then gently settled to its low point during the second half of the war, the Dutch line gradually peaked during its final decade. Dutch numbers fall sharply at the conclusion of the conflict, without losing much of their strength in the longer term; while the German Reformed figures bounced back with the re-establishment of Heidelberg and Marburg after 1652, without regaining their pre-war level. Although these two sub-systems follow diametrically opposite courses, they appear to be interlinked: between 1621 and 1652 in particular, the total number of annual matriculations throughout this system fluctuated within a very narrow band, never diverging from the average figure for this period by more than 13 percent. $^{32}$

\footnotetext{
${ }^{32}$ The main disruption to this system comes rather from Utrecht, which was raised to university status in 1636, and grew strongly after 1643, adding well over one hundred matriculations per year by the end of the war. But the new university's matriculation register is very unreliable for this period, averaging only five enrolments per year in some quinquennia and nearly 200 in others. Its arrival also heightens the need to distinguish matriculation rates from student numbers, since individual students increasingly matriculated in more than one Dutch university (as they had done previously in the German Reformed university system in its heyday). Source: Rijksuniversiteit te Utrecht (1886).
} 


\section{Part IV. Conclusion}

\section{Findings}

Perhaps the most significant result of this preliminary survey is methodological. Within the Holy Roman Empire-where a large number of universities were distributed relatively uniformly across the landscape and where matriculation registers were systematically compiled, preserved, edited, and published-matriculation rates appear to provide a sensitive barometer of the pressure of military events on local universities and on the confessions organized around them. These rates fluctuated, to be sure, in peacetime as well as wartime; but during the Thirty Years' War the most extreme fluctuations can usually be related to specific events, many of them central to the main narrative of the war, and the same holds for the general experiences of institutions across the duration of the conflict. A relatively small and easily assembled data set—containing only 2160 data points over a sixty-year period-provides a surprisingly revealing impression of the impact of three decades of conflict across most of the Empire, aside from the lands of the Czech crown (due to the absence of adequate data) and Imperial Italy (marginal to the war and excluded from this study).

More interesting still is the comparative potential of this analysis. Grouping the trajectories of individual universities by confession sharply distinguishes the experience of the three main confessions within the Empire. Clustering institutions geographically also suggests that some regions fared much better than others. Grouping by both confession and region shows that the dramatic losses inflicted on clusters of institutions within each confession were at least partially compensated by gains to other clusters of institutions within the same confession.

The losses were naturally concentrated in specific periods in which military events directly impacted specific areas. Reformed institutions collapsed in the years after the crushing of the Bohemian Revolt. Helmstedt suffered worst during the Danish-Lower Saxon phase. Greifswald and Rostock fared worst between the Danish defeat and the arrival of the Swedes. The Catholic institutions of central and southwestern Germany were devastated by the dramatic Swedish intervention of the early 1630s. The huge Saxon universities reached their nadir in the decade after the failure of the Peace of Prague. The Franco-Spanish War disrupted Douai and Leuven after 1635.

The gains corresponding to these losses were concentrated primarily in areas spared direct military involvement, whether entirely, relatively, or during specific phases of the conflict. Finding these winners requires ranging outside the theatre of war itself and therefore also outside the boundaries of the Holy Roman Empire. The Catholic confession enjoyed the best capacity to absorb its academic refugees within the confines of the Empire, thanks to the sheltered situation of Vienna, Graz, Salzburg, and Leuven, and the relative tranquility of Cologne. The impact of the Swedish assault nevertheless registered dramatically in momentary collapse of the southwest German Catholic institutions, which coincided with the huge spike of matriculation in Cracow in 1632-1635. The Reformed confession, by contrast, possessed almost no capacity to accommodate displaced students within the Empire, 
so the collapse of Heidelberg and its satellites helped fuel the sharp rise of the young Dutch universities from 1622 onward. The Lutheran confession once again fell between these two extremes. Rostock, Greifswald, and Erfurt benefitted to some degree from inclusion within a Swedish protectorate, and Königsberg experienced a war-time golden age. The provision of higher education expanded in Denmark and especially in Sweden and its Baltic possessions, and some of this expansion was both the fruit of military conquest and a precondition for sustaining empire-building activities on such an ambitious scale. But the Swedish and Danish universities were not integrated fully and reciprocally into the international Lutheran educational system in a manner analogous to the Dutch universities' place within the broader Reformed system: while the destinations of Scandinavians studying abroad were powerfully redirected from Germany to the Dutch Republic, the student bodies of Copenhagen and Uppsala were not transformed by large numbers of incoming German students fleeing the war.

The academic impact of the war therefore extended over a region much larger than the war's own theatre. This is not merely because natives of the war zones fled to study in more peaceful neighboring regions: an even greater cause was probably the disruption of the international academic trade routes of the pre-war period. Before the war, the dense population of universities inside the Empire attracted students from a huge region to its north and east which possessed few full universities. The devastation of the institutions at the center of this system transformed well-established patterns of academic exchange stretching across half the continent. Leiden is the most striking beneficiary precisely because competing Reformed institutions within the Empire had been most thoroughly destroyed. Her wartime gains were not due solely to Germans and Czechs fleeing the war: they also resulted from Norwegian, Swedish, Danish, Polish, Hungarian, Transylvanian, Swiss, and indeed Dutch students opting for the safety of the Dutch Republic to the war-torn regions to the east which their countrymen had previously preferred. In all likelihood, something similar applies to the wartime gains of Vienna, Cracow, and Königsberg, and further investigations may reveal smaller-scale effects in Scotland and England, Leuven, Orléan, and Padua, to name a few likely candidates.

\section{Prospects}

The transformation of these international patterns of academic migration cannot be adequately studied, however, merely on the basis of shifting matriculation rates. When matriculations collapse at the very moment when a university city is besieged or conquered, the inference from academic effect to military cause is robust. When rates drop as military events scythe through a university's catchment area, cutting it off from an established supply of students, the inference is less direct. When the devastation of institutions in one country redirects foreign and domestic students to alternative institutions in another country, the connection between falling rates in 
one region and rising ones in another needs to be confirmed by more painstaking study of data harvested from in individual matriculation entries themselves.

In this regard, this preliminary study has scarcely begun to exploit the full potential of these sources. Even the most basic matriculation records typically include the matriculant's name, place of origin, and date of entry. In some cases, this is supplemented by other information, including age, social status, and subject of study. The editors of most of the German registers provided indexes, translating both surnames and place names from Latin to German, while some include additional biographical information. The vast amounts of effort already invested in creating and editing these records will only be fully exploited when this meticulous scholarship has been transformed into a homogeneous body of highly granular, instantly navigable linked data. Existing technology can facilitate most stages of this transformation. Vernacular place names can be linked to modern gazetteers in semi-automated fashion, provided with geographical coordinates, and mapped. Simple algorithms can link records of the same student matriculating in multiple universities during the course of a peregrinatio academica, with the process of inference and degree of certainty recorded on the system. Unlike the Frequenzanalyse pursued in the current paper, analyses based on individual matriculation entries can be applied to those registers surviving in only fragmentary state for this period, ${ }^{33}$ and to new institutions founded in the region during or shortly after the war. ${ }^{34}$

Work on some of these tasks is already underway. Three of the largest matriculation registers relevant to this study-for Helmstedt, Rostock, and Leiden-have already been digitized and the former two published online. ${ }^{35}$ Meanwhile, a major collaborative project, the Repertorium Academicum Germanicum, has been collecting biographical and social data on all the graduated scholars of the Holy Roman Empire between 1250 and 1550. The result, published as an online prosopoographical database and atlas, will provide comprehensive 'who's who' of late medieval scholars in the region (RAG) (Schwinges, 2015; see also chapter by Schwinges in this volume). ${ }^{36}$ To date, nothing similar exists for the post-Reformation period.

Once coherent bodies of data have been assembled, they can be visualized and analyzed in a number of complementary ways. Analyses of the origins of students at individual universities merely requires the digitization of a single register. Analyzing competing clusters of universities in this way will show how catchment areas wax

\footnotetext{
${ }^{33}$ Including Copenhagen (missing before 1621), Cracow (lacking after 1641), Giessen (patchy from 1612-1649), Leuven (lacking before 1616), Marburg (lacking 1637-52), Olomouc (fragmentary in this period), Paderborn (lacking before 1637), Salzburg (lacking before 1637), and Utrecht (patchy before 1643).

${ }^{34}$ Including Strasbourg (1621), Altdorf (1622), Salzburg (1622), Tartu (1632), Kassel (1633), Trnava (1635), Utrecht (1636), Åbo (1640), Harderwijk (1648), Bamberg (1648), Duisburg (1654), Nijmegen (1655), and Košice (1657).

${ }^{35}$ Helmstedt: http://uni-helmstedt.hab.de/index.php?cPage =5\&sPage=matsearch; Rostock: http:// matrikel.uni-rostock.de/; and for Leiden see Zoeteman (2011).

${ }^{36}$ Further information and resources at http://www.rag-online.org/.
} 
and wane in response to military events on the ground: not only sieges and occupations of the cities themselves and major battles nearby, but also the presence of armies in neighboring regions or the disruption of sister institutions further afield. Alternatively, the destinations of students from an individual city, territory, or region-whether inside or outside the Empire - could be displayed, in order to understand how these shifted in the course of the war. A third data view would combine origins and multiple destinations to reconstruct the routes followed by students who visited more than one university in the course of their peregrinatio academica. This mode of analysis would reveal still more clearly how the linkages between networks of institutions shifted, in some cases dramatically, as the conflict moved from one theatre to another. Such work would build on excellent existing studies of the foreign travels of students from individual countries, including Denmark-Norway, Sweden, Prussia, Hungary, and Transylvania. ${ }^{37}$ Those matriculation registers which systematically record social status, age, or subject of study will allow even more complicated, multi-dimensional analysis. This approach could also answer the question of whether the decline in matriculations during the war represents a fall in the number of students or a decline in their mobility (Asche, 2011, pp. $162-163) .^{38}$

This leads to a still more general, final methodological conclusion regarding the media best adapted for understanding these patterns. Print has proved an excellent means of editing matriculation registers and tabulating matriculation rates. But prose is not well adapted to analyzing the highly granular data of this kind: hence the century since 1904, during which Eulenburg's data was so poorly exploited. Simple spreadsheets, and the graphs generated by them, now help reveal general patterns with relative ease; yet the limitations of these standard tools are also readily apparent. The multitude of static graphs accompanying this article has proved a cumbersome means for analyzing even this rather small data set, and these simple means will be even less well adapted to understanding the movements of hundreds of thousands of students between thousands of places of origin and dozens of different institutions against the background of complicated physical, political, and confessional geography and constantly changing military events. The next generation of work in this field therefore needs to supplement traditional prose description and static, two-dimensional graphs and maps with a much richer variety of interactive, dynamic, animated, multi-dimensional, full color visualizations designed to allow both expert and non-expert users to explore all the dimensions of the data at a variety of different tempos and scales. Unprecedented compilations of highly granular historical data have important new stories to tell, but telling them effectively will require new means of analyzing and visualizing those data.

\footnotetext{
${ }^{37}$ For Denmark-Norway: Helk (1987). For Sweden: Niléhn (1983b). For Poland: Żołądź-Strzelczyk (1996). For the Czech lands: Pešek and Šaman (1986). For Hungary: Szögi (2011).

${ }^{38}$ The dangers of travel during wartime may have deterred students from moving from one university to another in numbers similar to the periods before and after the war, encouraging them instead to study for longer periods of time at a smaller number institutions.
} 


\section{References}

Achelis, T. O. (1957). Deutsche Studenten auf nordischen Universitäten während des Dreißigjährigen Krieges [German students at Nordic universities during the Thirty Years' War]. Archiv für Kulturgeschichte, 39, 189-208. doi:https://doi.org/10.7788/akg-1957-jg11

Alschner, U. (1998). Universitätsbesuch in Helmstedt 1576-1810: Modell einer Matrikelanalyse am Beispiel einer norddeutschen Universität [University enrollment in Helmstedt 1576-1810: A model analysis of matriculations using the example of a north German university]. Wolfenbüttel: Braunschweigischer Geschichtsverein.

Andersson, A., Carlsson, A. B., Sandström, J., Sjögren, P., Brenner, S. O., \& Thimon, G. (Eds.), (1900). Uppsala universitets matrikel, 1595-1817: Vol. 1 [The matriculation register of Uppsala University, 1595-1817]. Uppsala: Akademiska Boktryckeriet.

Andritsch, J. (Ed.). (1977-1980). Die Matrikel der Universität Graz. [The matriculation register of Graz University] (Vols. 1-2). Graz: Akademische Druck und Verlagsanstalt.

Asche, M. (1995). Von einer hansischen Samthochschule zu einer mecklenburgischen Landesuniversität: Die regionale und soziale Herkunft der Studenten an der Universität Rostock in der Frühen Neuzeit [From a Hanseatic academy to a university for the duchy of Mecklenburg: The regional and social background of the students at the University of Rostock in the early modern period]. In P. Jakubowski \& E. Münch (Eds.), Universität und Stadt: Wissenschaftliche Tagung anlässlich des 575. Jubilaums der Eröffnung der Universitat Rostock (pp. 141-162). Rostock: University of Rostock.

Asche, M. (2000). Von der reichen hansischen Bürgeruniversität zur armen mecklenburgischen Landeshochschule: Das regionale und soziale Besucherprofil der Universitäten Rostock und Bützow in der Frühen Neuzeit (1500-1800) [From the rich university for Hanseatic citizens to a poor provincial university for Mecklenburg: the regional and social profile of students at the universities of Rostock and Bützow in the early modern period (1500-1800)]. Stuttgart: Steiner.

Asche, M. (2001). Frequenzeinbrüche und Reformen-Die deutschen Universitäten in den 1520er bis 1560er Jahren zwischen Reformation und humanistischem Neuanfang [Matriculation crises and reforms: The German universities in the 1520s to the 1560s between the Reformation and humanistic new beginnings]. In W. Ludwig (Ed.), Die Musen im Reformationszeitalter: Akten der Tagung der Stiftung Luthergedenkstätten in der Lutherstadt Wittenberg 14.-16 Oktober 1999 (pp. 53-96). Schriften der Stiftung Luthergedenkstätten in Sachsen-Anhalt: Vol. 1. Leipzig: Evangelische Verlags-Anstalt.

Asche, M. (2011). Der Dreißigjährige Krieg und die Universitäten im Heiligen Römischen Reich: Ein Fazit und viele offene Fragen [The Thirty Years' War and the universities of the Holy Roman Empire: Conclusions and many open questions]. In T. Kossert (Ed.), Universitäten im Dreißigjährigen Krieg (pp. 147-182). Militär und Gesellschaft in der Frühen Neuzeit: Vol. 15, Heft 1. Potsdam: Universitätsverlag Potsdam.

Asche, M., \& Gerber, S. (2008). Neuzeitliche Universitätsgeschichte in Deutschland: Entwicklungslinien und Forschungsfelder [Modern university history in Germany: Lines of development and fields of research]. Archiv für Kulturgeschichte, 90, 159-201. doi:https://doi. org/10.7788/akg.2008.90.1.159

Asche, M., \& Häcker, S. (2011). Matrikeln [Matriculation registers]. In U. Rasche (Ed.), Quellen zur frühneuzeitlichen Universitätsgeschichte. Typen-Bestände-Forschungsperspektiven (pp. 243-267). Wolfenbütteler Forschungen: Vol. 128. Wiesbaden: Harrassowitz.

Auerbach, I. (1984). Eine löbliche Hochschule, die gleich im Anfang wieder zergehen mußte: Zur Geschichte der ersten Kasseler Universität, 1633-1653 [A laudable university, which had no sooner begun than it was dissolved: On the history of the first university in Kassel, 1633-1653]. Prisma: Zeitschrift der Gesamthochschule Kassel, 32, 40-51.

Bergerhausen, H-W. (2010). Köln in einem eisernen Zeitalter: 1610-1686 [Cologne in an age of iron: 1610-1686]. Geschichte der Stadt Köln: Vol. 6. Cologne: Greven. 
Beyerle, K. (1900). Konstanz im dreißigjährigen Kriege: Schicksale bis zur Aufhebung der Belagerung durch Schweden. 1623-1633 [Constance in the Thirty Years' War: Its fortunes until the raising of the Swedish siege. 1628-1633]. Heidelberg: Winter.

Binz, G. (1917-1918). Literarische Kriegsbeute aus Mainz in schwedischen Bibliotheken [Literary war booty from Mainz in Swedish libraries]. Mainzer Zeitschrift, 12/13, 157-165.

Birket-Smith, S. (Ed.). (1890-1912). Kjфbenhavns Universitets Matrikel [Matriculation register of Copenhagen University]. Vols. 1-3. Copenhagen: Gyldendal.

Bock, O. (1908). Die Reform der Erfurter Universität während des Dreißigjährigen Krieges [The reform of Erfurt University during the Thirty Years' War]. Hallesche Abhandlungen zur neueren Geschichte: Vol. 46. Halle: Niemeyer.

Bonjour, E. (1960). Die Universität Basel von den Anfüngen bis zur Gegenwart, 1460-1960 [Basle University from its beginnings to the present, 1460-1960]. Basle: Helbing \& Lichtenhahn.

Bots, J. A. H., \& Frijhoff, W. T. M. (1985). Die studentenpopulatie van Franeker academie: een kwantitatief onderzoek (1585-1811) [The student population of Franeker University: a quantitative study (1585-1811)]. In G. T. Jensma, F. R. H. Smit, \& F. Westra (Eds.), Universiteit de Franeker, 1585-1811: Bijdragen tot de geschiedenis van de Friese hogeschool (pp. 56-72). Leeuwarden: Fryske Akademie.

Brockliss, L. W. B. (1987). French higher education in the seventeenth and eighteenth centuries: A cultural history. Oxford, UK: Clarendon Press.

Brück, A. P. (1972). Mainz vom Verlust der Stadtfreiheit bis zum Ende des Dreißigjährigen Krieges (1462-1648) [Mainz from the loss of civic freedom to the end of the Thirty Years' War (1462-1648)]. Geschichte der Stadt Mainz: Vol. 5. Düsseldorf: Rau.

Colenbrander, H. T. (1925). De Herkomst der Leidsche Studenten [The origin of Leiden's students]. In H. T. Colenbrander (Ed.), Pallas Leidensis MCMXXV (pp. 272-303). Leiden: Van Doesburgh.

de Ridder-Symoens, H. (1985). Buitenlandse studenten aan de Franeker universiteit 1585-1811 [Foreign students at Franeker University]. In G. T. Jensma, F. Smit, \& F. Westra (Eds.), Universiteit de Franeker, 1585-1811: Bijdragen tot de geschiedenis van de Friese hogeschool (pp. 73-89). Leeuwarden: Fryske Akademy.

de Ridder-Symoens, H. (Ed.). (1996). Universities in Early Modern Europe (1500-1800). A History of the University in Europe: Vol. 2. Cambridge, UK: Cambridge University Press

de Wal, J. (1886). Nederlanders: Studenten te Heidelberg [Dutch students in Heidelberg]. Handelingen en Mededeelingen van de Maatschappij der Nederlandsche Letterkunde te Leiden: Vol. 1885-1886. Leiden: E. J. Brill.

Deckers-Hauff, H., \& Setzler, W. (Eds.). (1977). Die Universität Tübingen von 1477 bis 1977 in Bildern und Dokumenten [Tübingen University from 1477 to 1977 in pictures and documents]. 500 Jahre Eberhard-Karls-Universität Tübingen: Vol. 3. Tübingen: Attempto Verlag.

Dehon, G. (1998). L'Université de Douai dans la tourmente (1635-1765): Heurs et malheurs de la Faculté des Arts [The University of Douai in the turmoil (1635-1765): Trials and tributations of the Faculty of Arts]. Histoire et civilisations: Vol. 609. Villeneuve d'Ascq: Presses universitaires du Septentrion.

Diderot, D, \& le Rond d'Alembert, J.-B. (Eds.). (1752-1772). Encyclopédie ou dictionnaire raisonné des sciences, des arts et des métiers [Encyclopedia or dictionary of sciences, arts and crafts] (Vols. 1-28). Paris: Briasson, David l'ainé, Le Breton, Durand.

Domarus von, M. (1902-1903). Der große Brand der Stadt Herborn im Jahre 1626 und die Kollekten für die Abgebrannten [The great fire of Herborn in 1626 and the collections for the victims]. Nassauische Annalen, 33, 297-364.

Du Rieu, W. N. (Ed.). (1875). Album Studiosorum Academiae Lugduno Batavae 1575-1875 [Matriculation register of Leiden University 1575-1875]. The Hague: Comitum apud Martinum Nijhoff.

Ellehøj, S., Grane, L., \& Hørby, K., (Eds.). (1979-1991). Kфbenhavns Universitet 1479-1979 [Copenhagen University 1479-1979], (Vol. 1-14). Copenhagen: G.E.C. Gads Forlag. 
Ernstberger, A. (1966). Die Universität Nürnberg-Altdorf während des Dreißigjährigen Krieges in ihrem Bestande bedroht [The University of Nuremberg-Altdorf during the Thirty Years' War threatened with extinction]. Munich: Verlag der Bayerischen Akademie der Wissenschaften.

Eulenburg, F. (1904). Die Frequenz der deutschen Universitäten von ihrer Gründung bis zur Gegenwart [Matriculation rates of the German universities from founding to the present]. Leipzig: Teubner.

Falckenhainer, W. (Ed.). (1893). Die Annalen und die Matrikel der Universität Kassel [The annals and matriculation register of the Kassel University]. Zeitschrift des Vereins für Hessische Geschichte und Landeskunde, n.F. 18, 190-326.

Fockema, A., Sybrandus, J., \& Meijer, T. J. (Eds.). (1968). Album studiosorum Academiae Franekerensis (1585-1811, 1816-1844) [Matriculation register of Franeker University (1585-1811, 1816-1844)]. Franeker: Wever.

Friedberg, E. (1909). Die Leipziger Juristenfakultät: Ihre Doktoren und ihr Heim. 1409-1909 [The Leipzig Law Faculty: Its doctors and their home. 1409-1909]. Festschrift zur Feier des 500 jährigen Bestehens der Universität Leipzig: Vol. 2. Leipzig: S. Hirzel.

Frijhoff, W. (1986a). Grandeur des nombres et misères des réalités: la courbe de Franz Eulenburg et la débat sur le nombre d'intellectuels en Allemagne, 1576-1815 [Grand numbers and miserable realities: Franz Eulenburg's curve and the debate on the number of intellectuals in Germany, 1576-1815]. In D. Julia, J. Revel, \& R. Chartier (Eds.), Les Universités europeennes du XVI au XVIII ${ }^{e}$ siècle: Histoire sociale des populations étudiantes (pp. 23-63). Recherches d'histoire et de sciences sociales: Vol. 1. Paris: Édition de l'École des Hautes Études en Sciences Sociales.

Frijhoff, W. (1986b). Université et marché de l'emploi dans la République des Provinces-Unies [University and labour market in the Dutch Republic]. In D. Julia, J. Revel, \& R. Chartier (Eds.), Les Universités europeennes $d u X V I^{e}$ au XVIII siècle: Histoire sociale des populations étudiantes (pp. 205-243). Recherches d'histoire et de sciences sociales: Vol. 1. Paris: Édition de l'École des Hautes Études en Sciences Sociales.

Frijhoff, W. (1996). Patterns. In H. de Ridder-Symoens (Ed.), Universities in Early Modern Europe (1500-1800) (pp. 43-110). A History of the University in Europe: Vol. 2. Cambridge, UK: Cambridge University Press.

Frohnhäuser, L. (1899). Gustav Adolf und die Schweden in Mainz und am Rhein [Gustavus Adolphus and the Swedes in Mainz and on the Rhine]. Archiv für hessische Geschichte und Altertumskunde, N.F. 2, 1-232.

Gall, F., \& Paulhart, H. (Eds.). (1974). Die Matrikel der Universität Wien:1579/II-1658/59 [The matriculation register of the University of Vienna:1579/II-1658/59]. Publikationen des Instituts für Österreichische Geschichtsforschung. VI. Reihe: Quellen zur Geschichte der Universität Wien, 1. Abteilung. Vienna: Bohlau.

Geuenich, D., \& Hantsche, I. (Eds.). (2007). Zur Geschichte der Universität Duisburg 1655-1818: Wissenschaftliches Kolloquium, veranstaltet im Oktober 2005 anlässlich des 350. Jahrestages der Gründung der alten Duisburger Universität [On the history of Duisburg University 1655-1818: Academic colloquium held in October 2005 on the occasion of the 350th anniversary of the founding of the old University of Duisburg]. Duisburg: Mercator-Verlag.

Grafton, A. (2006). The history of ideas: Precept and practice, 1950-2000 and beyond. Journal of the History of Ideas, 67, 1-32.doi:https://doi.org/10.1353/jhi.2006.0006

Häcker, S. (2011). Universität und Krieg: Die Auswirkungen des Dreißigjährigen Krieges auf die Universitäten Heidelberg, Tübingen und Freiburg [University and war. The impact of the Thirty Years' War on the universities of Heidelberg, Tübingen and Freiburg]. In T. Kossert (Ed.), Universitäten im Dreißigjährigen Krieg (pp. 98-123). Militär und Gesellschaft in der Frühen Neuzeit: Vol. 15, Heft 1. Potsdam: Universitätsverlag Potsdam.

Hammerstein, N. (1972). Jus und Historie: Ein Beitrag zur Geschichte des historischen Denkens an deutschen Universitäten im späten 17. und im 18. Jahrhundert [Law and history: A contribution to the history of historical thought in the German universities during the late 17th and 18th centuries]. Göttingen: Vandenhoeck und Ruprecht. 
Hammerstein, N. (1986/1987). The University of Heidelberg in the Early Modern Period: Aspects of its history as a contribution to its Sexcentenary. History of Universities, 6, 105-133.

Hautz, J. F. (1862-1864). Geschichte der Universität Heidelberg [History of Heidelberg University]. Vols. 1-2. Mannheim: J. Schneider.

Heidorn, G., Heitz, G., Kalisch, J., Olechnowitz, K.-F., \& Seemann, U. (Eds.). (1969). Geschichte der Universität Rostock 1419-1969. Festschrift zur Fünfhundertfünfzig-Jahr-Feier der Universität. [History of Rostock University 1419-1969. Publication celebrating the $550^{\text {th }}$ anniversary of the University] (Vols. 1-2). Berlin: Deutscher Verlag der Wissenschaften.

Helk, V. (1987). Dansk-Norske Studierejser fra reformationen til Enevaelden 1536-1660: Med en matrikel over studerende $i$ udlandet [Danish-Norwegian academic travel from the Reformation to Absolutism 1536-1616: With a register of students abroad]. Odense University studies in history and social sciences: Vol. 101. Odense: Odense University Publishing.

Hermelink, H., \& Kaehler, S. A. (1927). Die Philipps-Universität zu Marburg 1527-1927: 5 Kapitel aus ihrer Geshcichte (1527-1927) [The Philipps-University at Marburg 1527-1927: Five chapters from its history (1527-1927)]. Marburg: Elwert.

Historish Genootschap te Groningen (Ed.). (1915). Album studiosorum Academiae Groninganae [Matriculation register of Groningen University]. Groningen: J. B. Wolters.

Hofmeister, H. (1907). Die Universität Helmstedt zur Zeit des 30jährigen Krieges [Helmstedt University during the Thirty Years' War]. Zeitschrift des Historischen Vereins für Niedersachsen, 1907, 241-277.

Hotson, H. (2007). Commonplace learning: Ramism and its German ramifications, 1543-1630. Oxford, UK: Oxford University Press.

Hotson, $\mathrm{H}$. (forthcoming). The reformation of common learning: Post-Ramist pedagogy and the reception of the New Philosophy, 1618-c. 1670. Oxford, UK: Oxford University Press.

Ingemarsdotter, J. (2011). Ramism, rhetoric and reform: An intellectual biography of Johan Skytte (1577-1645). Uppsala Studies in History of Ideas: Vol. 42. Uppsala: Uppsala University.

Julia, D., \& Revel, J. (1989). Les étudiants et leurs études dans la France modern [Students and their studies in modern France]. In D. Julia \& J. Revel (Eds.), Les universités européennes $d u X V I^{e}$ au XVIII ${ }^{e}$ siècle: Histoire sociale des populations étudiantes (pp. 25-486). Histoire sociale des populations étudiantes: Vol. 2. Paris: Editions de l'École des Hautes Études en Sciences Sociales.

Julia, D., Revel, J., \& Chartier, R. (Eds.). (1986). Les Universités europeennes du XVI au XVIII siècle: Histoire sociale des populations étudiantes [European Universities from the 16th to the 18th Century: Social History of Student Populations]. Recherches d'histoire et de sciences sociales: Vol. 1. Paris: Édition de l'École des Hautes Études en Sciences Sociales.

Just, L., \& Mathy, H. (1965). Die Universität Mainz: Grundzüge ihrer Geschichte [Mainz University: The essentials of its history]. Mainz am Rhein: Mushake.

Kaniewska, I. (1986). La conjoncture étudiante de l'Université de Cracovie aux XVII ${ }^{\mathrm{e}}$ et XVIII ${ }^{\mathrm{e}}$ siécles [The student body of Cracow University in the seventeenth and eighteenth centuries]. In D. Julia, J. Revel, \& R. Chartier (Eds.), Les Universités europeennes du XVI au XVIII siècle: Histoire sociale des populations étudiantes (pp. 135-151). Recherches d'histoire et de sciences sociales: Vol. 1. Paris: Édition de l'École des Hautes Études en Sciences Sociales.

Kelley, D. (2002). The descent of ideas: The history of intellectual history. Aldershot: Ashgate.

Klüpfel, K. (1977). Geschichte und Beschreibung der Universität Tübingen [History and description of Tübingen University]. Geschichte und Beschreibung der Universität Tübingen: Vol. 2. Aalen: Scientia. (Original work published 1849)

Kosegarten, J. G. L. (1986). Geschichte der Universität Greifswald: 2 Teile in 1 Band [History of Greifswald University: 2 Parts in 1 Volume]. Aalen: Scientia. (Original work published 1856-1857)

Kossert, T. (Ed.). (2011), Universitäten im Dreißigjährigen Krieg [Universities in the Thirty Years' War]. Militär und Gesellschaft in der Frühen Neuzeit: Vol. 15, Heft 1. Potsdam: Universitätsverlag Potsdam. 
Krabbe, O. C. (1994). Aus dem kirchlichen und wissenschaftlichen Leben Rostocks: Zur Geschichte Wallensteins und des Dreißigjährigen Krieges [From the ecclesiastical and academic life of Rostock: On the history of Wallenstein and the Thirty Years' War]. Mitteldeutsche Forschungen: Vol. 112. Weimar: Böhlau. (Original work published 1863)

Lademacher, H. (Ed.). (1995). Oranien-Nassau, die Niederlande und das Reich [The House of Orange-Nassau, the Netherlands and the Empire]. Niederlande-Studien: Vol. 13. Münster: Lit.

Lagus, V. G. (Ed.). (1889-1906). Album studiosorum Academiae Aboensis MDCXL-MDCCCXXVII [Matriculation register of Åbo University 1640-1827]. (Vol. 1-2 and Supplement). Helsingfors: Tidnings- $\&$ tryckeri-aktiebolagets tryckeri.

Lamberts, E., \& Roegiers, J. (1990). Leuven University: 1425-1985. Leuven: Leuven University Press.

Langer, H. (2008). Die pommersche Landesuniversität Greifswald und das schwedische Reichsinteresse (1630-1720) [The Pommeranian university Greifswald and Swedish imperial interests (1630-1720)]. In P Wörster (Ed.), Universitäten im östlichen Mitteleuropa: Zwischen Kirche, Staat und Nation. Sozialgeschichtliche und politische Entwicklungen (pp. 85-103). Völker, Staaten und Kulturen in Ostmitteleuropa: Vol. 3. Munich: Oldenbourg Wissenschaftsverlag.

Langer, H. (2011). Die Universität Greifswald im Dreißigjährigen Krieg [Greifswald University during the Thirty Years' War]. In T. Kossert (Ed.), Universitäten im Dreißigjährigen Krieg (pp. 72-97). Militär und Gesellschaft in der Frühen Neuzeit: Vol. 15, Heft 1. Potsdam: Universitätsverlag Potsdam.

Lehmann, J. (1929). Die örtliche und soziale Herkunft der Königsberger Studenten 1544-1649 [The geographical and social origin of Königsberg's students, 1544-1649] (Doctoral dissertation). Leipzig: Borna.

Lindroth, S. (1976). A history of Uppsala University 1477-1977. Stockholm: Alqvist \& Wksell.

Lühr, G. (Ed.). (1925). Die Matrikel des päpstlichen Seminars zu Braunsberg 1578-1798 [The matriculation register of the Papal Seminar in Braunsberg / Braniewo 1578-1798]. Quellensammlung zur Geschichte Ermland: Vol. 11. Königsberg: Meyer.

Märker, A. (1993). Geschichte der Universität Erfurt 1392-1816 [History of Erfurt University 1392-1816]. Weimar: Hermann Böhlaus Nachfolger Weimar.

Menk, G. (1980). Das Restitutionsedikt und kalvinistische Wissenschaft. Die Berufung Johann Heinrich Alsteds, Philipp Ludwig Piscators und Johann Heinrich Bisterfelds nach Siebenbürgen [The edict of restitution and calvinist learning. The Calling of Johann Heinrich Alsted, Philipp Ludwig Piscator and Johann Heinrich Bisterfeld to Transylvania]. Jahrbuch der Hessischen Kirchengschichtlichen Vereinigung, 31, 29-63.

Menk, G. (1981). Die Hohe Schule Herborn in ihrer Frühzeit (1584-1669): Ein Beitrag zum Hochschulwesen des deutschen Kalvinismus im Zeitalter der Gegenreformation [The Herborn Academy in its early years (1584-1669): A study of German Calvinist academic affairs in the age of the Counter-Reformation]. Veröffentlichungen der Historischen Kommission für Nassau: Vol. 30. Wiesbaden: Historische Kommission für Nassau.

Methuen, E. (1988). Die alte Universität [The old university]. Kölner Universitätsgeschichte: Vol. 1. Cologne: Böhlau.

Mühlpfordt, G. (1983). Die Oder-Universität 1506-1811 [The Oder-University 1506-1811]. In G. Haase \& J. Winkler (Eds.), Die Oder-Universität Frankfurt: Beiträge zu ihrer Geschichte (pp. 19-72). Weimar: Böhlau.

Niléhn, L. (1983a). Sweden and Swedish students abroad: The $17^{\text {th }}$ century and its background. In G. Rystad (Ed.), Europe and Scandinavia: Aspects of the process of integration in the $17^{\text {th }}$ century (pp. 101-122). Lund Studies in International History: Vol. 18. Solna: Esselte Studium.

Niléhn, L. (1983b). Peregrinatio academica: det svenska samhället och de utrikes studieresorna under 1600-talet [Peregrinatio academica: Swedish society and areas of foreign study in the $17^{\text {th }}$ century]. Lund: CWK Gleerup.

Nischan, B. (1994). Prince, people, and confession: The second Reformation in Brandenburg. Philadelphia: University of Pennsylvania Press. 
Oestreich, G. (1960). Grafschaft und Dynastie Nassau im Zeitalter der konfessionellen Kriege [The county and dynasty of Nassau in the age of confessional wars]. Blätter für deutsche Landesgeschichte, 96, 22-49.

Pagès, G. (1970). The Thirty Years' War 1618-1648. London: Adam and Charles Black.

Parker, G. (1984). The Thirty Years' War. London: Routledge.

Parrott, D. (1987). The causes of the Franco-Spanish War of 1635-59. In J. Black (Ed.), The origins of war in Early Modern Europe (pp. 72-111). Edinburgh: John Donald Publishers Ltd.

Pelizaeus, L. (2005). Die Universität Erfurt zwischen den Konfessionen 1615-1655 [Erfurt University between the confessions 1615-1655]. In P. C. Hartmann (Ed.), Forschungen $z u$ Kurmainz und dem Reichserzkanzler (pp. 29-52). Mainzer Studien zur Neueren Geschichte: Vol. 17. Frankfurt a. M.: Lang.

Persijn, A. (1959). Pfälzische Studenten und ihre Ausweichuniversitäten während des Dreißigjährigen Krieges [Palatine students and their alternative universities during the Thirty Years' War]. (Doctoral dissertation). University of Mainz. Waldfischbach: Südwestdeutsche Verlagsdruckerei Hornberger.

Pešek, J., \& Šaman, D. (1986). Les étudiants de Bohême dans les universités et les académies d'Europe central et occidentale entre 1596 et 1620 [Bohemian students at the universities and academies of central and western Europe between 1596 and 1620]. In D. Julia, J. Revel, \& R. Chartier (Eds.), Les Universités europeennes du XVI ${ }^{e}$ au XVIII siècle: histoire sociale des populations étudiantes (pp. 89-111). Recherches d'histoire et de sciences sociales: Vol. 1. Paris: Édition de l'École des Hautes Études en Sciences Sociales.

Prantl, C. (1872). Geschichte der Ludwig-Maximilians-Universität Ingolstadt, Landshut, München. Zur Festschrift ihres vierhundertjährigen Bestehens im Auftrage es Akademischen Senates [The history of the Ludwig Maximilian University Ingolstadt, Landshut, Munich. To the commemoration of its 400th anniversary on behalf of the Academic Senate]. Vols. 1-2. Munich: Christian Kaiser.

Press, V. (1985). Kurfürst Maximillian I. von Bayern, die Jesuiten und die Universität Heidelberg im Dreißigjährigen Krieg 1622-1649 [Elector Maxmillian I of Bavaria, the Jesuits, and Heidelberg University during the Thirty Years' War]. In W. Doerr (Ed.), Mittelalter und frühe Neuzeit: 1386-1803 (pp. 314-370). Semper Apertus. Sechshundert Jahre Ruprecht-KarlsUniversität Heidelberg 1386-1986: Vol. 1. Berlin: Springer.

Prüser, F. (1928). Bremen und die Universität Marburg im ersten Jahrhundert ihres Bestehens [Bremen and Marburg University during the first century of its existence]. Bremisches Jahrbuch, 31, 181-267.

Rasche, U. (Ed.). (2011). Quellen zur frühneuzeitlichen Universitätsgeschichte: TypenBestände-Forschungsperspektiven [Sources for the history of the early modern university: Types—collections-research perspectives]. Wolfenbütteler Forschungen: Vol. 128. Wiesbaden:Harrassowitz.

Rathmann, L. (Ed.). (1984). Alma Mater Lipsiensis: Geschichte der Karl-Marx-Universität Leipzig [Alma Mater Lipsiensis: History of the Karl Marx University, Leipzig]. Leipzig: Edition Leipzig.

Redlich, V. (Ed.). (1933). Die Matrikel der Universität Salzburg: 1639-1810 [The matriculation register of Salzburg University: 1639-1810]. Salzburg: University of Salzburg.

Richter, W. (2011). Die vier mitteldeutschen Universitäten in Leipzig, Wittenberg, Jena und Erfurt im Dreißigjährigen Krieg: Eine Frequenzanalyse [The four middle-German universities in Leipzig, Wittenberg, Jena and Erfurt during the Thirty Years' War: An analysis of matriculation rates]. In T. Kossert (Ed.), Universitäten im Dreißigjährigen Krieg (pp. 41-56). Militär und Gesellschaft in der Frühen Neuzeit: Vol. 15, Heft 1. Potsdam: Universitätsverlag Potsdam.

Rijksuniversiteit te Utrecht, (Ed.). (1886). Album Studiosorum Academiae Rheno-Traiectinae MDCXXXVI-MDCCCLXXXVI [Matriculation register of Utrecht University 1636-1886]. Utrecht: J. L. Beijers et J. van Boekhoven.

Roberts, M. (1953-1958). Gustavus Adolphus: A History of Sweden 1611-1632 (Vols. 1-2). London: Longman. 
Rudersdorf, R. (1982). Der Weg zur Universitätsgründung in Gießen: Das geistige und politische Erbe Landgraf Ludwigs IV. von Hessen-Marburg [The way to the foundation of a university in Giessen: The intellectual and political legacy of Landgraf Ludwig IV of Hesse-Marburg]. In P. Moraw \& V. Press (Eds.), Academia Gissensis: Beiträge zur älteren Giessener Universitätsgeschichte (pp. 45-82). Veröffentlichungen der Historischen Kommission für Hessen: Vol. 45. Marburg: Elwert.

Rudersdorf, M. (2009). Weichenstellung für die Neuzeit: Die Universität Leipzig zwischen Reformation und Dreißigjährigem Krieg 1539-1648/1660 [Setting a course for modernity: The University of Leipzig between the Reformation and the Thirty Years' War 1539-1648 / 1660]. In E. Bünz, M. Rudersdorf, \& D. Döring (Eds.), Spätes Mittelalter und frühe Neuzeit 1409-1830/31 (pp. 327-515). Geschichte der Universität Leipzig 1409-2009: Vol. 1. Leipzig: Leipzig University Press.

Schillings, A. H. (Ed.). (1962-1963). Matricule de l'Université de Louvain [Matriculation register of the University of Leuven]. Vols. 5-6. Collection de chroniques Belge inédites: Vol. 33. Brussels: Kiessling et Cie \& P. Imbreghts.

Schindling, A. (1977). Humanistische Hochschule und freie Reichsstadt: Gymnasium und Akademie in Straßburg 1538-1621 [Humanist higher education and imperial free city: The gymnasium and academy in Strasbourg 1538-1621]. Veröffentlichungen des Instituts für Europäische Geschichte Mainz: Vol. 77. Wiesbaden: Steiner.

Schindling, A. (1978). Straßburg und Altdorf. Zwei humanistische Hochschulgründungen von evangelischen freien Reichsstädten [Strasbourg and Altdorf. Two humanist university foundations of Protestant free imperial cities]. In P. Baumgart \& N. Hammerstein (Eds.), Beiträge zu Problemen deutscher Universitätsgründungen der frühen Neuzeit (pp. 149-189). Wolfenbütteler Forschungen: Vol. 4. Nendeln: KTO Press.

Schneppen, H. (1960). Niederländische Universitäten und deutsches Geistesleben: Von der Gründung der Universität Leiden bis ins späte 18. Jahrhundert [Dutch universities and German intellectual life: From the foundation of Leiden University to the latter 18th century]. Neue münstersche Beiträge zur Geschichtsforschung: Vol. 6. Münster: Aschendorffsche Verlagsbuchhandlung.

Schonath, W. (1967). Bibliothecae Academiae Herbipolensis Libri: Versprengte Schätze der Universitäts-Bibliothek Würzburg in Schloß Pommersfelden [Scattered treasures of the Würzburg University Library in Pommersfelden Castle]. Quellen und Beiträge zur Geschichte der Universität Würzburg. Beiheft: Vol. 4. Neustadt an der Aisch: Degener \& Co.

Schönauer, T. (2006). Die Studenten aus Ingolstadt zwischen 1392 und 1600: Eine sozialhistorischstatistische Studie (Teil 1) [Students from Ingolstadt between 1392 and 1600: A socialhistoricalstatistical study (Part 1)]. Sammelblatt des Historischen Vereins Ingolstadt, 115, 204-285.

Schönauer, T. (2007). Ingolstadt in der Zeit des Dreißigjährigen Krieges: Soziale und wirtschaftliche Aspekte der Stadtgeschichte [Ingolstadt in the era of the Thirty Years' War: Social and economic aspects of city history]. Beiträge zur Geschichte Ingolstadts: Vol. 4. Ingolstadt: Stadt Ingolstadt.

Schönauer, T. (2011). Landesfestung und Universität: Ingolstadt im Dreißigjährigen Krieg [Territorial defense and the university: Ingolstadt during in the Thirty Years' War]. In T. Kossert (Ed.), Universitäten im Dreißigjährigen Krieg (pp. 57-71). Militär und Gesellschaft in der Frühen Neuzeit: Vol. 15, Heft 1. Potsdam: Universitätsverlag Potsdam.

Schreiner, K. (1985). Die Katastrophe von Nördlingen: Politische, wirtschaftliche und kulturelle Folgen einer Schlacht für Land und Leute des Herzogtums Württemberg [The catastrophe of Nördlingen: Political, economic and cultural consequences of a battle for the the land and people of the duchy of Württemberg]. Jahrbuch des Historischen Vereins für Nördlingen und das Ries, $27,39-90$.

Schultze, J. (1964). Von der Reformation bis zum Westfälischen Frieden (1535-1648) [From the Reformation until the Peace of Westphalia (1535-1648)]. Die Mark Brandenburg: Vol. 4. Berlin: Duncker \& Humblot. 
Schwinges, R. C. (2015). Das Repertorium Academicum Germanicum (RAG): Ein digitales Forschungsvorhaben zur Geschichte der Gelehrten des alten Reiches (1250-1550) [The German Academic Repertory: A digital research project on the history of the scholars of the old Empire (1250-1550)]. In R vom Bruch, M Kintzinger, O Auge, \& S Piotrowski (Eds.), Professorenkataloge 2.0. Ansätze und Perspektiven webbasierter Forschung in der gegenwärtigen Universitäts- und Wissensgeschichte (pp. 215-232). Jahrbuch für Universitätsgeschichte: Vol. 16 (2013). Stuttgart: Steiner.

Seth, I. (1956). Die Universität Greifswald und ihre Stellung in der schwedischen Kulturpolitik 1637-1815 [The University of Greifswald and its position in Swedish cultural policy 1637-1815]. Berlin: Deutscher Verlag der Wissenschaften.

Siefert, A. (1996). Das höhere Schulwesen: Universitäten und Gymnasien [Higher education: Universities and gymnasia]. In N. Hammerstein (Ed.), 15. bis 17. Jahrhundert. Von der Renaissance und der Reformation bis zum Ende der Glaubenskämpfe (pp. 197-374). Handbuch der deutschen Bildungsgeschichte: Vol. 1. Munich: C.H. Beck.

Siilivask, K. (Ed.). (1985). A history of Tartu University 1632-1982. Tallinn: Perioodika.

Specht, T. (1987). Geschichte der ehemaligen Universität Dillingen (1549-1804) und der mit ihr verbundenen Lehr- und Erziehungsanstalten [A history of the former University of Dillingen (1549-1804) and of the educational institutions associated with it]. Aalen: Scientia. (Original work published 1902)

Staehelin, A. (1957). Geschichte der Universität Basel 1632-1818 [History of Basle University 1632-1818]. Vols. 1-2. Studien zur Geschichte der Wissenschaften in Basel: Vols. 4-5. Basle: Helbing \& Lichtenhahn.

Steinmetz, M. (Ed.). (1958-1962). Geschichte der Universität Jena 1548/58-1958: Festgabe zum vierhundertjährigen Universitätsjubiläum [History of Jena University 1548/58-1958: Publication celebrating the 400 anniversary of the university]. Vols. 1-2. Jena: Gustav Fischer Jena.

Stelling-Michaud, S. (Ed.). (1959-1980). Le livre du recteur de l'Académie de Genève: 1559-1878 [Matriculation register of the Geneva Academy: 1559-1878]. Vols. 1-6. Travaux d'humanisme et renaissance: Vol. 33. Geneva: Librairie Droz.

Stieda, W. (1917). Die Universität Rostock und Wallenstein [Rostock University and Wallenstein]. Jahrbuch des Vereins für Mecklenburgische Geschichte und Altertumskunde, 81, 75-88.

Stone, L. (1964). The educational revolution in England, 1560-1640. Past and Present, 28, 41-80. Retrieved from http://www.jstor.org/stable/649877

Stritmatter, R. (1977). Die Stadt Basel während des Dreißigjährigen Krieges. Politik, Wirtschaft, Finanzen [The city of Basel during the Thirty Years' War. Politics, economy, finance]. Bern: Lang.

Szögi, L. (2011). Magyarországi diákok németországi egyetemeken és akadémiákon 1526-1700 [Hungarian students at universities and academies in Germany from 1526 to 1700]. Budapest: Eötvös Loránd Tudományegyetem Levéltára.

Tering, A. (Ed.). (1984). Album academicum der Universität Dorpat (Tartu) 1632-1710 [The matriculation register of the University of Dorpat (Tartu) 1632-1710]. Publicationes Bibliothecae Universitatis Litterarum Tartuensis: Vol. 5. Tallinn: Valgus.

Triebs, M. (1995). Die Medizinische Fakultat der Universitat Helmstedt (1576-1810): Eine Studie $z u$ ihrer Geschichte unter besonderer Berücksichtigung der Promotions- und Übergangsdisputationen [The medical faculty of Helmstedt University (1576-1810): A study of its history, with particular reference to doctoral and transitional disputations]. Repertorien zur Erforschung der frühen Neuzeit: Vol. 14. Wiesbaden: Otto Harrassowitz.

Troesch, B. (1969). Origines géographiques et sociales des étudiants immatriculés à l'Académie de Genève (1559-1798) [Geographical and social origins of the students matriculated at the Geneva Academy (1559-1798)]. Mémoire compl. licence sciences sociales. Geneva: Université de Genève.

van Nimwegen, O. (2014). The Dutch-Spanish War in the Low Countries 1621-1648. In O. Asbach \& P. Schröder (Eds.), The Ashgate research companion to the Thirty Years' War (pp. 163-175). London: Ashgate Publishing. 
Vann, J. A. (1984). The making of a state: Württemberg 1593-1793. Ithaca: Cornell University Press.

von Rommel, C. (1820-1843). Geschichte von Hessen [History of Hesse] (Vols. 1-8). Cassel: Perthes.

von Selle, G. (1956). Geschichte der Albertus-Universität zu Königsberg in Preußen (2nd ed.) [History of the Albertus University in Königsberg in Prussia]. Der Göttinger Arbeitskreis: Vol. 145. Würzburg: Holzner. (Original work published 1944)

von Wegele, F. X. (1969). Geschichte der Universität Würzburg [History of Würzburg University]. Vols. 1-2. Würzburg: Scientia Verlag. (Original work published 1882)

Wachernagel, H. G. (Ed.). (1951-1980). Die Matrikel der Universität Basel [The matriculation register of Basle University]. Vols. 1-5. Basle: Verlag der Universitätsbibliothek.

Weber, R. (1979). Würzburg und Bamberg im Dreißigjährigen Krieg: Die Regierungszeit des Bischofs Franz von Hatzfeldt 1631-1642 [Würzburg and Bamberg during the Thirty Years' War: The rule of Bishop Franz von Hatzfeldt 1631-1642]. Würzburg: Echter-Verlag.

Weiß, U. (2008). Die Stiftungsprofessur für evangelische Theologie Augsburgischen Bekenntnisses an der älteren Erfurter Universität in ihrer Frühzeit (1566-1632) [The endowed chair in evangelical theology of the Augsburg Confession at the older Erfurt University in its early period (1566-1632)]. In J. Rogge (Ed.), Tradieren-Vermitteln-Anwenden: Zum Umgang mit Wissensbeständen in spätmittelalterlichen und frühneuzeitlichen Städten (pp. 189-230). Beiträge zu den Historischen Kulturwissenschaften: Vol. 6. Berlin: Akademie Verlag.

Whatmore, R., \& Young, B. (Eds.). (2016). A companion to intellectual history. Wiley Blackwell companions to world history. Malden: Wiley-Blackwell.

Wilson, P. H. (2009). Europe's tragedy: A history of the Thirty Years' War. London: Allen Lane.

Wolf, K. (1930). Hessische Studenten auf niederländischen Universitäten im 17. Jahrhundert [Hessian students at Dutch universities in the 17th century]. Hessische Chronik, 17, 97-112.

Wolf, K. (1935). Nassauer Studenten auf den Hochschulen zu Leiden, Groningen, Utrecht, Harderwijk und Genf in der Zeit bis 1700 [Students from Nassau at the universities of Leiden, Groningen, Utrecht, Harderwijk and Geneva in the period before 1700]. Nassauische Annalen, $55,139-147$.

Zaschka, B. (1993). Die Lehrstühle der Universität Tübingen im Dreißigjährigen Krieg: Zur sozialen Wirklichkeit von Professoren im vorklassischen Zeitalter [The professorships of Tübingen University during the Thirty Years' War: On the social reality of professors in the preclassical age]. Tübingen: Attempto-Verlag.

Zathey, J., \& Barycz, H. (1950). Album studiosorum Universitatis Cracoviensis: T. 4, Continens nomina studiosorum ab anno 1607 ad annum 1642 [Matriculation register of Cracow University: Containing the names of the students from 1607 to 1642]. Cracow: Sumptibus Universitatis Jagellonicae Cracoviensis.

Zedler, G., \& Sommer, H. (Eds.). (1908). Die Matrikel der Hohen Schule und des Paedagogiums zu Herborn [The matriculation register of the academy and gymnasium in Herborn]. Veröffentlichungen der Historischen Kommission für Nassau: Vol. 5. Wiesbaden: J. F. Bergmann.

Zirr, A. (2009). Die Schweden in Leipzig 1642-1650: Ein stadtgeschichtlicher Überblick zur Spätphase des Dreißigjährigen Krieges [The Swedes in Leipzig 1642-1650: A civic-historical survey of the late phase of the Thirty Years' War]. In M. Cottin, D. Döring, \& C. Friedrich (Eds.), Stadtgeschichte. Mitteilungen des Leipziger Geschichtsvereins e.V.: Jahrbuch 2009 (pp. 67-87). Beucha: Sax-Verlag.

Zirr, A. (2010). Stadt und Universität Leipzig im Dreißigjährigen Krieg [The city and university of Leipzig during the Thirty Years' War]. In D. Döring (Ed.), Stadt und Universität Leipzig: Beiträge zu einer 600-jährigen wechselvollen Geschichte (pp. 145-166). Quellen und Forschungen zur Geschichte der Stadt Leipzig: Vol. 1. Leipzig: Leipziger Universitätsverlag.

Zirr, A. (2011). Universität und fremde Besatzung: Die Alma mater Lipsiensis während der schwedischen Herrschaft über Leipzig 1642 bis 1650 [University and alien occupation: Leipzig University during the Swedish rule over Leipzig from 1642 to 1650]. In T. Kossert (Ed.), 
Universitäten im Dreißigjährigen Krieg (pp. 18-40). Militär und Gesellschaft in der Frühen Neuzeit: Vol. 15, Heft 1. Potsdam: Universitätsverlag Potsdam.

Zoeteman, M. (2011). De studentenpopulatie van de Leidse universiteit, 1575-1812 [The student population of Leiden University, 1575-1812] (Doctoral dissertation). Leiden: Leiden University Press.

Żołądź-Strzelczyk, D. (1996). Peregrinatio academica. Studia mtodzieży polskiej z Korony i Litwy na akademiach $i$ uniwersytetach niemieckich $w$ XVI i pierwszej potowie XVII wieku [Studies of Polish youth from the Kingdom of Poland and Lithuania at German academies and universities in the sixteenth and first half of the 17th century]. Seria Psychologia i pedagogika: Vol. 106. Poznań: UAM.

Zopf, H. (1927). Schweden und Kaiserliche in der Mark Brandenburg anno 1631 [Sweden and Imperial forces in Mark Brandenburg in 1631]. In Landesdirektor der Provinz Brandenburg (Ed.), Brandenburgisches Jahrbuch: 2. Band (pp. 30-44). Berlin: Deutsche Bauzeitung.

Zsoldos, A. (Ed.). (1990). Matricula Universitatis Tyrnaviensis 1635-1701 [Matriculation register of Trnava University 1635-1701]. Fejezetek az Eötvös Loránd Tudományegyetem történetéból: Vol. 11. Budapest: Eötvös Loránd Tudományegyetem.

Open Access This chapter is licensed under the terms of the Creative Commons Attribution 4.0 International License (http://creativecommons.org/licenses/by/4.0/), which permits use, sharing, adaptation, distribution and reproduction in any medium or format, as long as you give appropriate credit to the original author(s) and the source, provide a link to the Creative Commons license and indicate if changes were made.

The images or other third party material in this chapter are included in the chapter's Creative Commons license, unless indicated otherwise in a credit line to the material. If material is not included in the chapter's Creative Commons license and your intended use is not permitted by statutory regulation or exceeds the permitted use, you will need to obtain permission directly from the copyright holder. 